Article

\title{
Late Holocene Glacier Dynamics in the Miyar Basin, Lahaul Himalaya, India
}

\author{
Sanjay Deswal ${ }^{1, *}$ (D), Milap Chand Sharma ${ }^{2}$, Rakesh Saini ${ }^{3}$ (D) Pritam Chand $^{2}$ (D), \\ Navin Juyal ${ }^{4}$, Ishwar Singh ${ }^{2}$, Pradeep Srivastava ${ }^{5}$, Ajai ${ }^{6}$ and I.M. Bahuguna ${ }^{6}$ \\ 1 Department of Geography, Govt. College Dujana, Haryana 124102, India \\ 2 Centre for the Study of Regional Development, Jawaharlal Nehru University, New Delhi 110067, India; \\ milap@jnu.ac.in (M.C.S.); pritamiirs@gmail.com (P.C.); ishwarjnu@gmail.com (I.S.) \\ 3 Department of Geography, Dr. Hari Singh Gour Central University, Sagar 470003, India; \\ rakesh83jnu@hotmail.com \\ 4 Physical Research Laboratory, Ahmedabad 380015, India; navin@prl.res.in \\ 5 Wadia Institute of Himalayan Geology, Dehradun 248001, India; pradeep@wihg.res.in \\ 6 Space Application Centre, Ahmedabad 380015, India; ajai@sac.isro.gov.in (A.); \\ imbahuguna@sac.isro.gov.in (I.M.B.) \\ * Correspondence: sdeswal.jnu@gmail.com; Tel.: +91-967-120-0240
}

Academic Editors: Ulrich Kamp and Jesús Martínez Frías

Received: 5 May 2017; Accepted: 25 July 2017; Published: 4 August 2017

\begin{abstract}
Detailed field mapping of glacial and paraglacial landforms and optical dating from these landforms are used to reconstruct the early Holocene glaciation in the semi-arid region of Miyar basin, Lahaul Himalaya. The study identifies three stages of glaciation, of decreasing magnitude and termed, from oldest to youngest, the Miyar stage (MR-I), Khanjar stage (KH-II), and Menthosa advance (M-III). The oldest glacial stage (MR-I) has been established on the basis of detailed geomorphological evidence such as U-shaped valley morphology, trimlines, and truncated spurs. It is speculated to be older than the global Last Glacial Maximum (gLGM) based on the magnitude of $\triangle E L A$ (Equilibrium-Line Altitude, 606m). No evidence of glacier expansion recorded from the basin correlates with the period of the gLGM. The second stage (KH-II) is well represented by extensive depositional features such as lateral and terminal moraines, drumlins, and lacustrine fills that have been constrained within $10 \pm 1$ to $6.6 \pm 1.0 \mathrm{ka}$ (Optically stimulated luminescence-OSL-ages), dating it to the early Holocene advance following the Younger Dryas cooling event. Exceptionally young glacial records of expansion are limited within a few hundred meters of the present termini of tributary glaciers and correlates with the 18th-century cooling event. Records of this glacial advance, termed the Menthosa advance, are clearly noticed in some tributary valleys.
\end{abstract}

Keywords: Holocene; glaciation; Lahaul Himalaya; LGM; ELA; OSL

\section{Introduction}

The Himalayan-Tibetan (H-T) orogeny altered large-scale climate systems including the Asian monsoon and considerably influenced the regional and global atmospheric circulation that may have played a key role in the onset of Quaternary glaciation [1-6]. Information on the geographic extent and magnitude of Quaternary glaciations in this largest glacierized area outside the polar region is important for understanding the climatic and tectonic evolution of this giant orogenic system [7-10]. Practically in the context of contemporary global warming, climate variability, and associated societal impacts, it is important to characterize and quantify past glacial changes for a better assessment of regional and global forcing factors for future glacier behavior as a water resource [11,12]. Yet, despite the geological and societal importance of this region, the nature and dynamics of glaciers of this 
region throughout the Quaternary are not well understood $[11,13,14]$. The growing availability of chronological data in recent years has emerged, yet there is no general consensus concerning the timing, extent, and climatic forcing of glaciations in the Himalayan region [12,15,16].

The Himalaya is fed by two dominant climate systems, viz. the Indian Summer Monsoon (ISM) and the mid-latitude Westerlies. The relative role of these two dominant climate systems varied significantly throughout the Quaternary, resulting in asynchronous glaciation across the orogen [4]. In addition, numerous studies have attempted to link long-term (thousands of years) variations influenced by changes in northern hemisphere insolation, and shorter-term variations (decadal) explained by changes within the climate system, to mountain glacier fluctuations throughout the Quaternary [11,13,16-19]. Moreover, there are also strong microclimatic variations within individual mountain ranges and valleys, potentially exerting strong controls over glaciation [20,21]. Glaciers situated in orographically shielded areas are suggested to be more sensitive to changes in precipitation; whereas, glaciers that receive high amounts of precipitation are more sensitive to changes in temperature [22]. During the mid-Holocene, increased snow accumulation resulting from high precipitation was much smaller than the reductions in ablation caused by lower temperatures attributed to increased cloudiness and evaporative cooling [23]. Thus, despite the agreement on the importance of monsoon strength for glacier behavior in the Himalayan realm, the exact mechanisms, timing, and geographic extent of monsoonal influence are debatable [12]. Recent studies highlight the considerable complexity in the timing and extent of glacial advances in the Himalayan-Tibetan region and propose more dates from the poorly observed areas of the Himalaya [13].

Very few studies have been carried out on glaciation in the Lahaul Himalaya, and absolute glacial chronologies are still limited [24,25]. Evidence of the presence of glaciers in the past is preserved in the form of moraines, ice transported blocks, and smoothened and striated rock surfaces, U-shaped valleys, hanging valleys, glacial lakes, and glacial-fluvial deposits. With this consideration, the present study adds to the understanding of the response to global warming in a westerly-dominated valley, specifically the role of local and regional climatic factors in driving glaciation of the Miyar basin of Lahaul Himalaya in the northwestern part of India. No study has ever been carried out in the Miyar basin on Quaternary glaciation, although the basin's well-preserved glacial landforms and sediments provide evidence of major glaciations. Moreover, it lies in a transitional climatic zone between the dry steppe climate of the Zankar Himalaya in the north, and the humid Himalayan climate in the south of Pir Panjal, and thus the terrain provides an opportunity to understand the role of temporal changes in the summer monsoon and mid-latitude Westerlies in driving glaciation.

\section{Study Area}

The Miyar basin, covering an area of $963.85 \mathrm{~km}^{2}$, is a major tributary basin of the Chenab River that flows within Himachal Pradesh state of India (Figure 1). It consists the most significant cluster of glaciers in Lahaul Himalaya such as Miyar Glacier-one of the largest valley glaciers in the Himachal or Lahaul Himalaya. The basin extends between $32^{\circ} 42^{\prime} 36^{\prime \prime} \mathrm{N}$ and $33^{\circ} 15^{\prime} 24^{\prime \prime} \mathrm{N}$, and $76^{\circ} 40^{\prime} 12^{\prime \prime} \mathrm{E}$ and $77^{\circ} 1^{\prime} 15^{\prime \prime} \mathrm{E}$ within the Great Himalayan tract, with altitudes ranging from $2800 \mathrm{~m}$ to over $6000 \mathrm{~m}$ a.s.l. It lies in the Central Crystalline Zone of the Lahaul Himalaya that crops out as a large-scale dome structure, called the Gianbul dome within the Miyar basin [26-30]. Climatically, Lahaul is sandwiched between the monsoon dominated areas of the Pir Panjal to the south and the mid-latitude Westerlies dominated arid areas of Ladakh to the north of the Great Himalayan Range. The high altitude and configuration of mountain ranges play an important role in governing rainfall pattern and type in this region. 


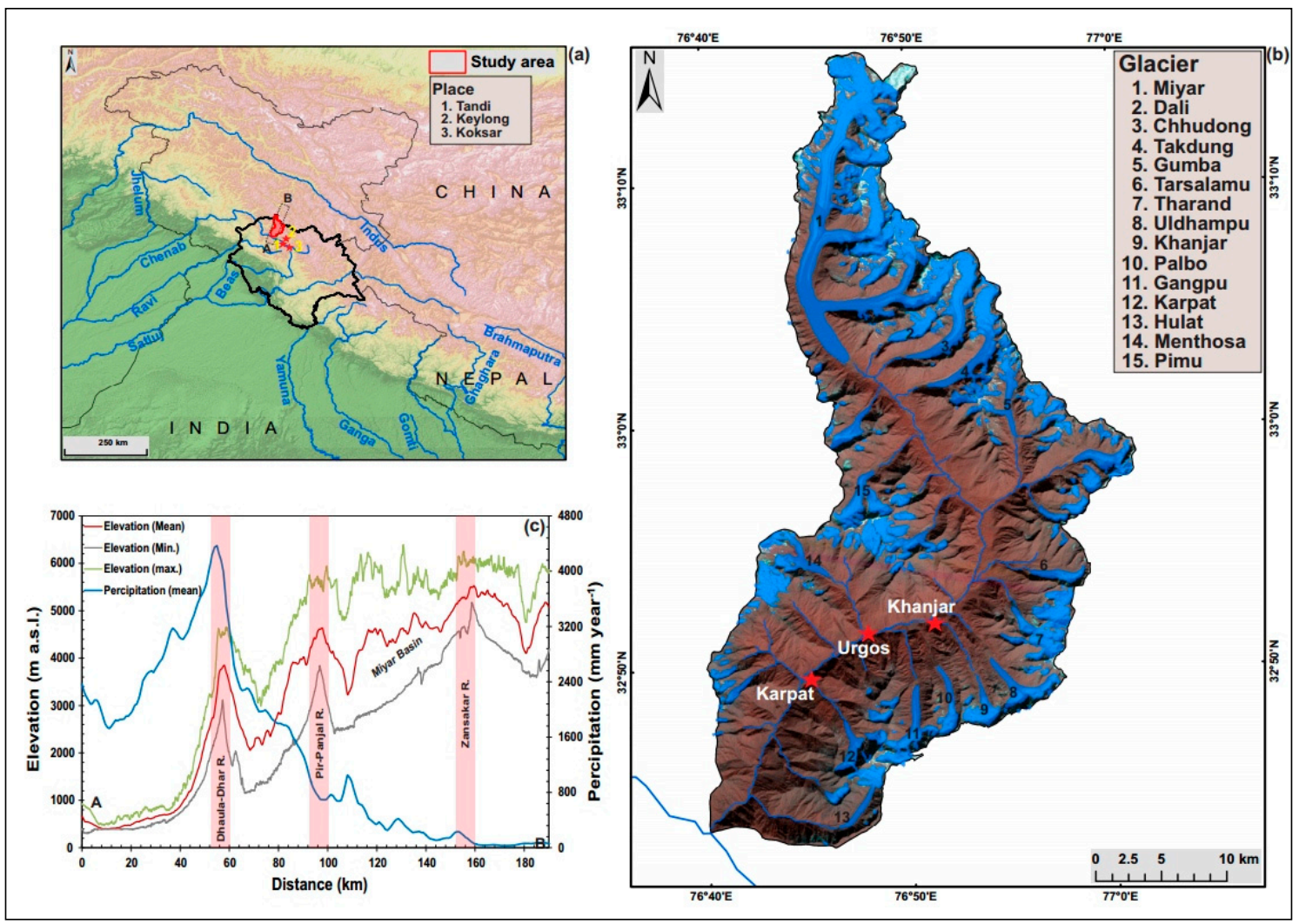

Figure 1. The Miyar basin within the Lahaul Himalaya, India: (a) study area; (b) present glacier distribution; (c) elevation and precipitation longitudinal valley profiles.

Maximum precipitation falls in the winter months (December to March), whereas the monsoon months from June to September contribute insignificant amount of rainfall. The monsoon winds are weak in the region because of the barrier posed by the Pir Panjal range on the southern flank. Therefore, most of the precipitation falls in the winter months as snowfall as a result of western disturbances. Field investigation and satellite images indicate that most of the glaciers have extensive debris cover in their ablation zone. The basin is characterized with large debris flows in the form of fans at many places. As mentioned earlier, the climate of the Miyar basin is semi-arid and high-magnitude, low-frequency rainfall events are common in such environments. Debris flow fans are also evidence of catastrophic debris floods in the past (e.g., at Chhaling and Karpat villages).

\section{Material and Methods}

\subsection{Geomorphological Mapping}

Geomorphological mapping is acritical part of the relative dating methods used for the reconstruction of former glaciation. Detailed geomorphological mapping was carried out in the basin at Tharang end-moraine complex, Gumba end-moraine complex, and at the fore-field of Miyar glacier using Robotic Total Station (Trimble S6, Sunnyvale, CA, USA) along with GPS measurements and terrestrial photography that were used as reference data to facilitate mapping from satellite imagery (IRS LISS IV 2013). Pre-field geomorphological maps, based upon visual interpretation of high to medium spatial resolution images of IRS-P6 and Google Earth images, were validated, improved, and classified. We used the on-screen digitization method to map various glacial landforms on a scale of 1:5000. The ASTER Global Digital Elevation Model (GDEM v2) was used for extracting topographical information, mapping 3D characteristics of landforms, assessing glaciers' topographical characteristics, Equilibrium-Line Altitude (ELA) calculation, and determining the role of surface 
processes in landscape evolution. Landforms of diverse origin assembled alongside the length of major rivers and tributary valleys. Three sets of landforms are distinctly identifiable: the first is related to the oldest glaciation (trimlines, truncated spurs, and glacial trough); others are related to the second glacial episode that includes lateral and terminal moraines descending to the main valley from tributary glaciers; and finally, there are extensive reworked features formed during the post-glacial phase (Figure 2). These landforms show a definite spatial sequence in evolution with respect to the dominant process, i.e., glacier expansion and post-glacial reworking. Post-glacial processes have been responsible for major modifications, thus providing present-day landscape configuration and obliteration of the depositional signature of the oldest glaciation. Additionally, the stratigraphic position of the lateral and terminal moraines, degree of lithification, vegetation cover, crest morphology (sharp to round crested), and elevation were used to reconstruct the extent of glaciers [31].
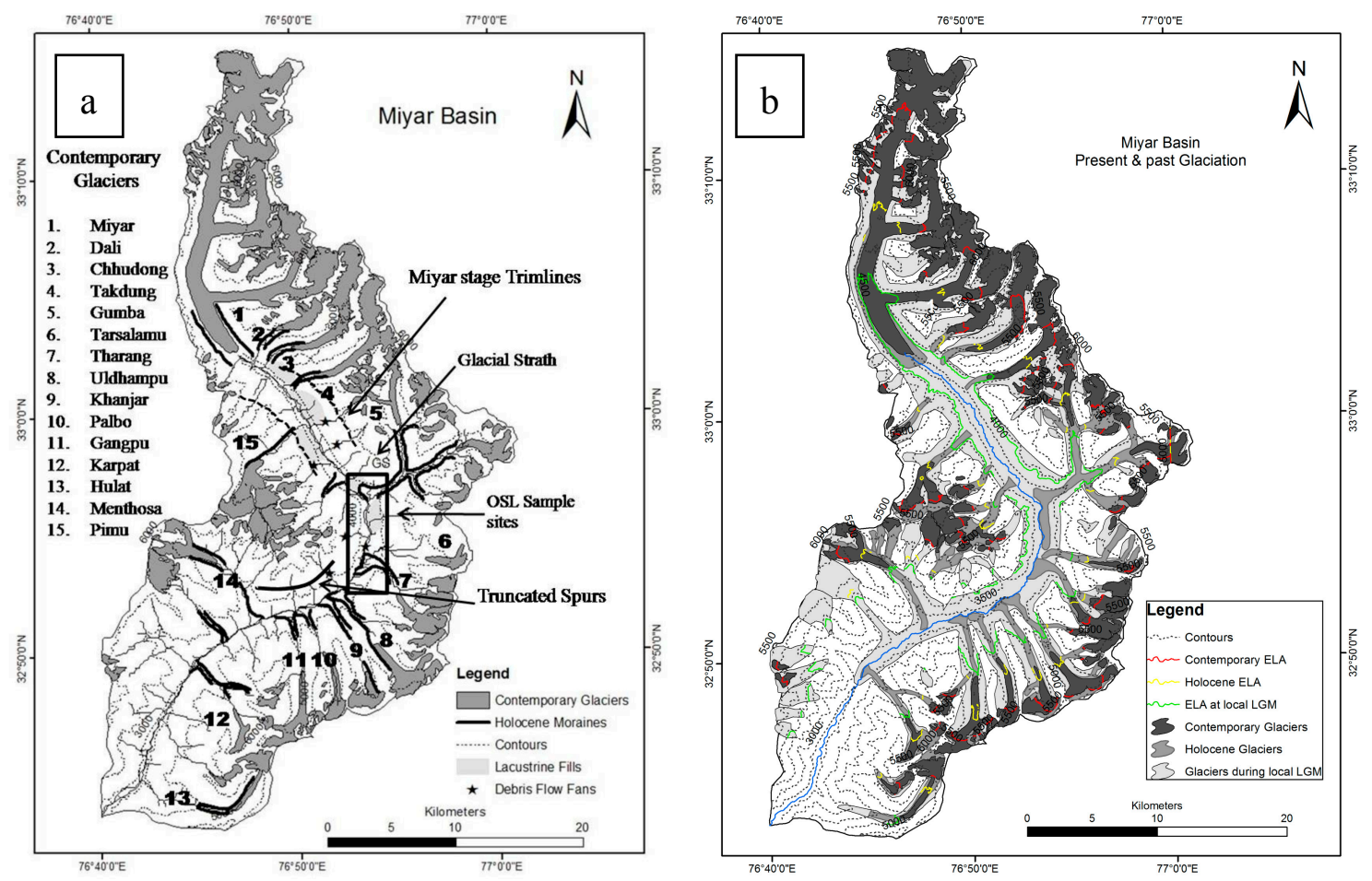

Figure 2. (a) General geomorphology of the Miyar basin marking the Optically stimulated luminescence (OSL) sample locations and various geomorphic features associated with the oldest glacial event and early Holocene glacier expansion. (b) Contemporary glacier outlines as compared with outlines during local Last Glacial Maximum (LGM) and early Holocene. The change in Equilibrium-Line Altitude (ELA) is also shown.

\subsection{Equilibrium-Line Altitudes}

The equilibrium line marks the position where, over a period of one year, accumulation of snow is exactly balanced by ablation. A glacier advances when the ELA lowers, and retreats when the ELA rises [23]. Hence, ELA reconstruction helps to infer the glacial history in the absence of numerical ages and to uncover the paleoclimatic conditions [32]. The modern ELA is estimated using remotely-sensed data by extracting the snow line altitude (SLA), viable alternative for the ELA, at the end of the ablation season [33]. The SLA was mapped for the major valley glaciers using multi-temporal Landsat images from 2002 to 2013, acquired at the end of the ablation season, when snow cover is at its annual minimum and approximates the annual ELA [33-35]. The SLA/ELA is demarcated by the difference in reflectance between clean ice and dirty ice from the satellite images. This estimate is tested using Accumulation Area Ratio (AAR) that ranges from 0.2 to 0.6 with an average of 0.42 and accords well 
with the range of values for debris covered glaciers [36]. Errors are estimated by averaging the standard deviations associated with each year's SLA/ELA. Moreover, it is suggested that the ELA of the glacier lies at the hypsometric maximum [37]. In the Miyar basin, the hypsometric maximum of the valley glaciers is very close to the calculated ELA (Figure 3).

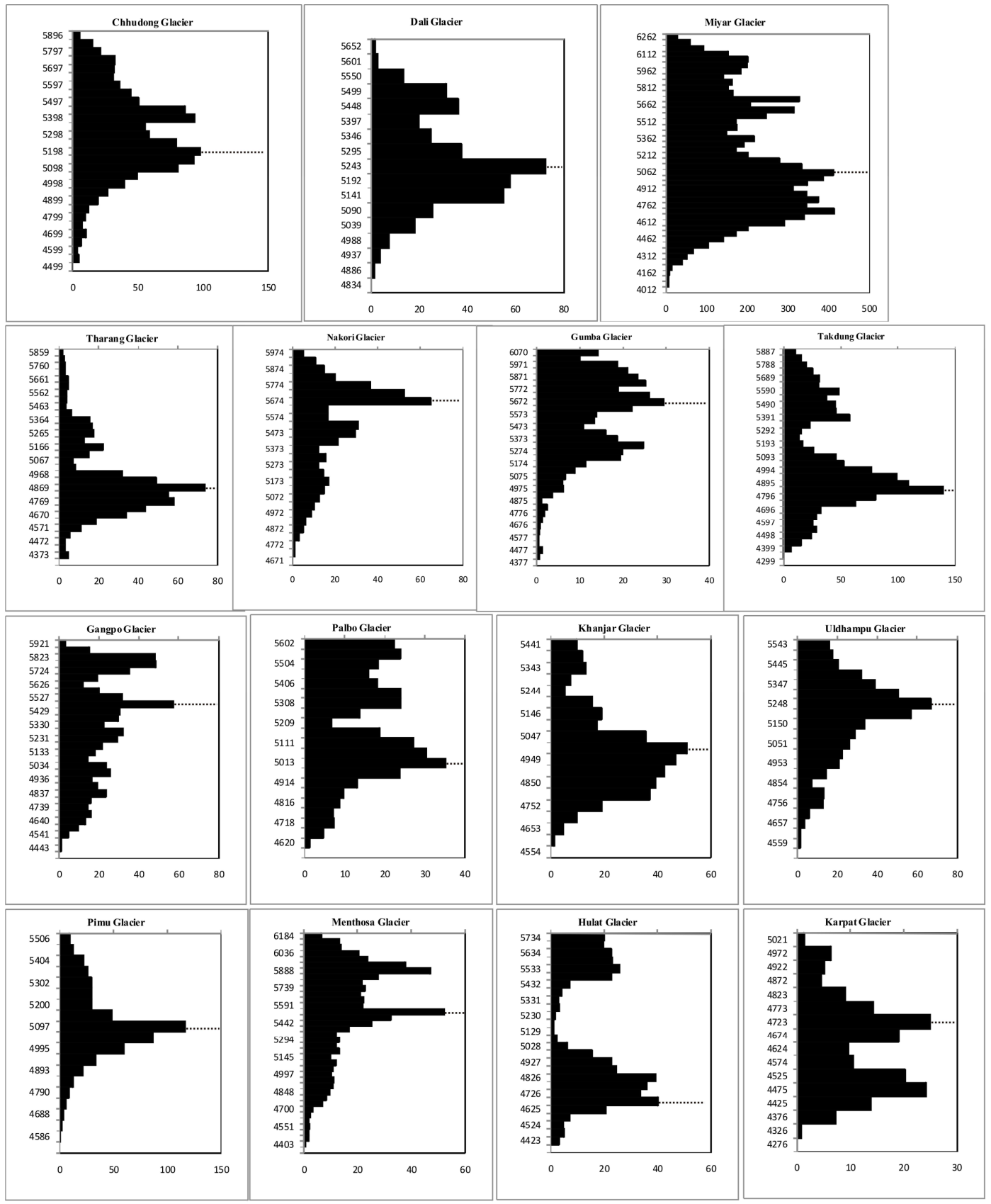

Figure 3. Hypsometry of the glaciers in the Miyar basin used for ELA estimation denoted by hypsometric maximum. Area in hectares is given on the x-axis, while elevation is given on the $y$-axis.

It has been suggested that a combination of different methods of ELA reconstruction should be applied to achieve a reliable estimation of paleo-ELAs [36]. We used the following methods: (i) AAR, (ii) Terminus-to-Headwall Altitude Ratio (THAR), and (iii) Area-weighted Mean (AWM). AAR is one of the more widely used methods and assumes that, under steady-state conditions, the accumulation area of the glacier occupies some fixed proportion of the glacier area and implicitly takes into account 
the glacier's mass balance gradient [36]. Steady-state AARs for mid- and high-latitude glaciers lie in the range $0.5-0.8$ [38-40], with typical values around 0.55-0.65 [40]. It has been observed that the effect of extensive debris cover lowers the steady-state AAR, because a larger ablation area is required to balance accumulation [36]. Recent glaciological studies on the less debris-covered Chhota-Shigri [41] and Dokriani glaciers [42] in the Himachal and Garwhal Himalaya suggested zero net-mass balance AARs of $\sim 0.61$ and 0.7 and an associated ELA of $\sim 4950 \mathrm{~m}$ and $\sim 5000 \mathrm{~m}$, respectively. Mass balance studies on debris-covered glaciers in the Baspa catchment, on the other hand, reveal significantly higher zero net-mass balance AARs of $\sim 0.44$ and ELAs of $\sim 5100-5150 \mathrm{~m}$ a.s.l. when compared to the abovementioned glaciers [43]. In addition, the mass balances of the debris-covered Chorabari Glacier in the monsoon-dominated central Himalaya show an AAR of $\sim 0.45$ [44]. AAR is calculated using the hypsometry of the glaciers derived from ASTER DEMv2 using the following equation:

$$
\mathrm{AAR}=A_{c} /\left(A_{c}+A_{b}\right)
$$

where $A_{c}$ is the accumulation area, $A_{b}$ is the ablation area, and $A_{c}+A_{b}$ is the total area.

The THAR method assumes that the ELA is proportional to the elevation of the terminus and head of the glacier. Values determined for THAR range from 0.35 to 0.5 , with 0.4 as the most commonly applied value [45,46], but debris cover can raise the THAR as high as 0.6-0.8 [47]. Recent mass balance studies of the Himalayan glaciers suggested that the THAR for the debris-covered Chorabari Glacier is $\sim 0.5$, whereas for the less debris-covered Dokriani and Chhota-Shigri glaciers it is $\sim 0.6$ [42]. This study used values of 0.5 and 0.6 using the following equation:

$$
\operatorname{ELA}=A_{t}+\operatorname{THAR}\left(A_{t}-A_{h}\right)
$$

where $A_{t}$ is the terminus altitude and $A_{h}$ is the headwall altitude.

An advantage of THAR, beyond its ease of use, is that the data may be examined to determine the best THAR value empirically. However, this method is oversimplified as it does not take into account the glacier hypsometry or mass balance. In addition, defining the effective upper limit of the glacier can be problematic or impossible in some cases.

The AWM method [48] is based on the assumption that the amount of ablation decreases linearly with height-in contrast to AAR, which assumes that the accumulation area comprises a certain fraction of the total glacier surface. AWM is calculated using the following equation:

$$
x=A_{i} \cdot h i / A_{i}
$$

where $A_{i}$ is the glacier area in $\mathrm{km}^{2}$ and $h_{i}$ is the midpoint altitude in meters.

The ELA is determined by a number of factors: glacier morphology and its topographical characteristic, the source of accumulation such as avalanches or direct snowfall, and the nature of the covered surface of the glaciers. In the absence of glaciological mass balance measurements for the investigated glaciers, steady-state ELAs and the corresponding AARs are unknown. Moreover, calculated ELA using the AAR $(0.44,0.56,0.6)$, THAR (0.5 and 0.6), AWM, mean, and median methods provide a wide range of values (Figure 4). Thus, a combination of different methods of ELA reconstruction has been used to obtain the reliable estimation of paleo-ELAs in the study area.

Climate change has been widely inferred from the difference between the former and modern ELA, known as the $\triangle E L A$ [36]. Glaciologists commonly multiply the simple adiabatic lapse rate $(\mathrm{d} T / \mathrm{dZ})$ by $\triangle E L A$ to estimate the paleo-temperature changes. However, the paleo-climatic interpretations based on $\triangle E L A$ require reliable data on adiabatic lapse rates. Very few studies on $\mathrm{d} T / \mathrm{dZ}$ have been carried out in the high altitudes of the NW Himalayas, e.g., at Baltoro Glacier in the Karakoram $\left(8.4{ }^{\circ} \mathrm{C} / \mathrm{km}\right)$ [49], South Pulu $\left(6.3^{\circ} \mathrm{C} / \mathrm{km}\right)$ and Parchu glaciers in the Ladakh Himalaya $\left(9.1^{\circ} \mathrm{C} / \mathrm{km}\right)$, Hamtah $\left(11.2^{\circ} \mathrm{C} / \mathrm{km}\right)$ [50], Chhota-Shigri $\left(6.5^{\circ} \mathrm{C} / \mathrm{km}\right)$ and Dokriani glaciers in the Garhwal Himalaya $\left(6{ }^{\circ} \mathrm{C} / \mathrm{km}\right)[51,52]$. By taking into consideration the different lapse rate values, we used the widely 
used average slope air temperature lapse rate of $6.5^{\circ} \mathrm{C} / \mathrm{km}$ for computing the temperature decline associated with the three glacial stages.

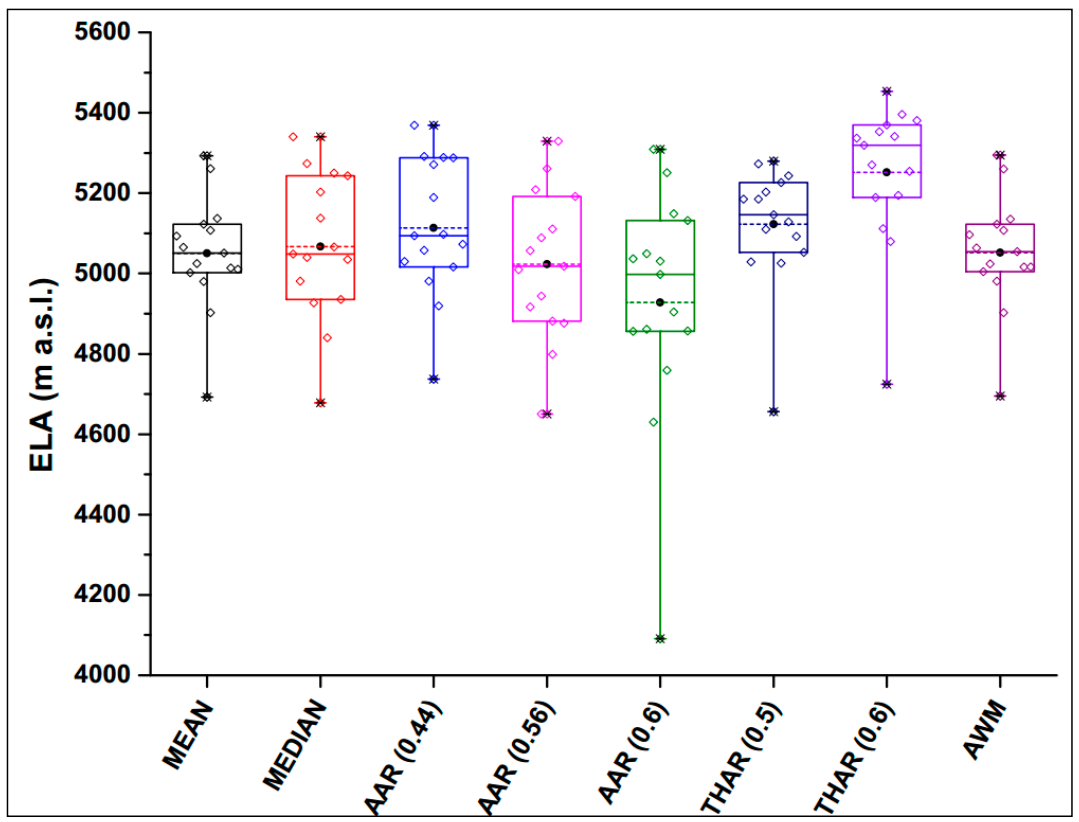

Figure 4. ELAs of major valley glaciers in the Miyar basin estimated using different methods. Note the wide range of ELA values. AAR: Accumulation Area Ratio; THAR: Terminus-to-Headwall Altitude Ratio; AWM: Area-weighted Mean.

In areas for which no precipitation and humidity data are available, as generally is the case in the Himalaya, it is difficult to provide a quantified estimate of paleo-precipitation. To some extent this problem can be circumvented by reconstructing the past ice volume, which provides a crude assessment of relative changes in paleo-precipitation [31,53]. The total ice volume of the glacier has been estimated using the slope-dependent ice thickness method [54,55]. Recently, it was reported that slope-dependent ice thickness estimates provide better results than the Volume-to-Area (V-A) approach, since it considers the glacier morphology, slope, and other physical parameters instead of constants used in V-A [54].

\subsection{Optically Stimulated Luminescence Dating}

After establishing the relative chronology based on landform association, samples were collected for optically stimulated luminescence (OSL) dating as per prescribed procedures [56]. The samples were collected using $18 \mathrm{~cm}$ long and 3-4 cm diameter toughened rubber and steel tubes from the quartz bearing sections. The suitability of sediments for OSL dating was taken into consideration while collecting the samples for analysis [57,58]. Care was taken while collecting samples to avoid any exposure to light. The site conditions and locations are given in Table 1. Sample preparation and luminescence measurements were carried out at Thermo-Luminescence (TL) dating lab of the Wadia Institute of Himalayan Geology, Dehradun and the Physical Research Laboratory (Ahmedabad, India). The samples were opened in subdued red light laboratory conditions. Optical dating was carried out on quartz minerals that are extracted using the standard chemical pretreatment and procedure. This involves the removal of carbonate and organic carbon using $1 \mathrm{~N}$ hydrochloric acid $(\mathrm{HCl})$ and $30 \%$ hydrogen peroxide $\left(\mathrm{H}_{2} \mathrm{O}_{2}\right)$. Accordingly, $200 \mathrm{~g}$ of coarse-grained quartz sample were treated with a $10 \%$ volume-to-volume dilution of concentrated (37\%) $\mathrm{HCl}$ followed by $30 \% \mathrm{H}_{2} \mathrm{O}_{2}$ to remove any possible carbonates and organic material, respectively. The samples were then dried at temperature $<50{ }^{\circ} \mathrm{C}$ and sieved to separate the $90-150 \mu \mathrm{m}$ diameter fraction of grain size. Further, the quartz and 
feldspar separation is done by magnetic separation [59] using a Frantz Magnetic Separator (Model LB-1 of S. G. Frantz Company Inc., Milwaukee, WI, USA). The quartz rich-fraction after separation was etched with $40 \%$ hydrofluoric (HF) acid for 80 min with constant magnetic stirring to etch any remaining feldspars and the outer alpha-irradiated portion of grains during burial, followed by $12 \mathrm{~N}$ $\mathrm{HCl}$ treatment for $30 \mathrm{~min}$ to dissolve any insoluble fluorides that may have formed. The samples were then oven-dried at a temperature $<50{ }^{\circ} \mathrm{C}$ and sieved again as a further purification step to remove any grains reduced in volume by this etching procedure. The purity of the quartz grains (for feldspar contamination) was checked by infrared stimulated luminescence (IRSL), indicating negligible feldspar contribution close to the background. Optical dating measurements were made using an automated Risø TL/OSL reader (DTU Nutech, Roskilde, Denmark) [60]. Grains were deposited in a monolayer on $9.65 \mathrm{~mm}$ diameter stainless steel discs using silicone oil (Silkospray ${ }^{\mathrm{TM}}$ ), to make medium aliquots containing 100 grains covering a diameter of $3 \mathrm{~mm}$ [61]. The samples were stimulated using blue $(470 \pm 20 \mathrm{~nm})$ light emitting diodes (LED), and detection optics comprises a bi-alkali type photomultiplier tube (PMT) (EMI 9835QA) coupled with a 7.5mm Hoya U-340 filter (emission $330 \pm 35 \mathrm{~nm}$ ). Beta irradiations were carried out using an on-plate ${ }^{90} \mathrm{Sr} /{ }^{90} \mathrm{Y}$ beta source with a dose rate of $5.49 \mathrm{gy} / \mathrm{ka}$. The elemental concentrations of uranium, thorium, and potassium for environmental dose rate estimation were carried out using the high-purity Germanium detector. The samples were sealed in plastic boxes and kept for $\sim 15$ days to attain radioactive equilibrium between radium, radon and some of its daughter isotopes. The errors of measurement (both systematic and statistical uncertainties) are $<5 \%$. An average water content of $15 \pm 5 \%$ was used and cosmic ray contributions in dose rate were calculated as per the suggested method [62].

Table 1. Site description of OSL samples.

\begin{tabular}{|c|c|c|}
\hline Sample ID & Location & Site Description \\
\hline MI-1 & $\begin{array}{l}32^{\circ} 53^{\prime} 38.40^{\prime \prime} \mathrm{N} \\
76^{\circ} 53^{\prime} 09.60^{\prime \prime} \mathrm{E}\end{array}$ & Lacustrine sediment at Tharang, 2 feet from the top. \\
\hline MI-2 & $\begin{array}{l}32^{\circ} 56^{\prime} 45.60^{\prime \prime} \mathrm{N} \\
76^{\circ} 53^{\prime} 06.50^{\prime \prime} \mathrm{E}\end{array}$ & Lacustrine sediment at Gumba, 6.5 feet from the top. \\
\hline MI-3 & $\begin{array}{l}32^{\circ} 56^{\prime} 09.77^{\prime \prime} \mathrm{N} \\
76^{\circ} 53^{\prime} 56.33^{\prime \prime} \mathrm{E}\end{array}$ & Section of a Drumlin at Thampatan, 5 feet from the top. \\
\hline MI-4 & $\begin{array}{l}32^{\circ} 55^{\prime} 47.34^{\prime \prime} \mathrm{N} \\
76^{\circ} 53^{\prime} 48.68^{\prime \prime} \mathrm{E}\end{array}$ & Lacustrine sediments at Thampatan, 5 feet from the top. \\
\hline MI-5 & $\begin{array}{l}32^{\circ} 53^{\prime} 45.24^{\prime \prime} \mathrm{N} \\
76^{\circ} 53^{\prime} 13.82^{\prime \prime} \mathrm{E}\end{array}$ & Exposed section of terminal moraine at Tharang, 11 feet from the top. \\
\hline MI-6 & $\begin{array}{l}32^{\circ} 56^{\prime} 47.40^{\prime \prime} \mathrm{N} \\
76^{\circ} 53^{\prime} 11.70^{\prime \prime} \mathrm{E}\end{array}$ & Lacustrine sediment at Gumba, 6 feet from the top. \\
\hline MI-7 & $\begin{array}{l}32^{\circ} 56^{\prime} 47.40^{\prime \prime} \mathrm{N} \\
76^{\circ} 53^{\prime} 11.70^{\prime \prime} \mathrm{E}\end{array}$ & Lacustrine sediment at Gumba, 8 feet from the top. \\
\hline
\end{tabular}

The equivalent doses $\left(D_{e}\right)$ were measured using modified single aliquot regeneration (SAR) protocol [63] with preheat of $240{ }^{\circ} \mathrm{C}$ for $10 \mathrm{~s}$ and cut heat of $200^{\circ} \mathrm{C}$. The preheat temperature was decided based on the preheat plateau test. OSL were measured at $125^{\circ} \mathrm{C}$ for $40 \mathrm{~s}$; prior to every OSL measurement, IRSL was measured at $50{ }^{\circ} \mathrm{C}$ for $100 \mathrm{~s}$ to remove any contribution from feldspar. Dose growth curves were constructed using five regeneration dose points including one point to estimate the recuperation and another point to estimate reliability of sensitivity correction (recycling ratio). On average, 40 aliquots for each sample were analyzed, out of which 9-29 aliquots met the criteria, having recycling ratios within $10 \%$ of the unity and $<5 \%$ recuperation. For age computation, we used the Central Age Model (CAM) that uses over-dispersion (OD) values for multi-grain $D_{e}$ ranges from $0 \%$ to $35 \%$; whenever the OD value was $>35 \%$, we used the Minimum Age Model (MAM) [64-67]. 


\section{Results}

Glacial and associated landforms were mapped based on morpho-stratigraphic positions, morphology and relationships of lateral/terminal moraines, degree of weathering of forms and surfaces, degree of lithification, and vegetation cover. Accordingly, two major events and one minor event of glaciation are discerned in the Miyar basin and are discussed below (Figure 5). These have been named, from oldest to youngest, the Miyar stage (MR-I), Khanjar stage (KH-II), and Menthosa advance (M-III). Landform evolution in the basin is a direct result of the advance and retreat of glaciers, which generate the glacial process, which in turn creates erosional and depositional features in the glacial geomorphic landscape. The advance produces distinctive depositional features, which epitomize landforms' evolution. However, no sedimentary landform record has been left behind by the oldest stage glaciation (MR-I). The retreat of the KH-II stage glaciers produces distinctive interwoven morainic features linked with the sub-stages of glacier retreat (Figure 6).

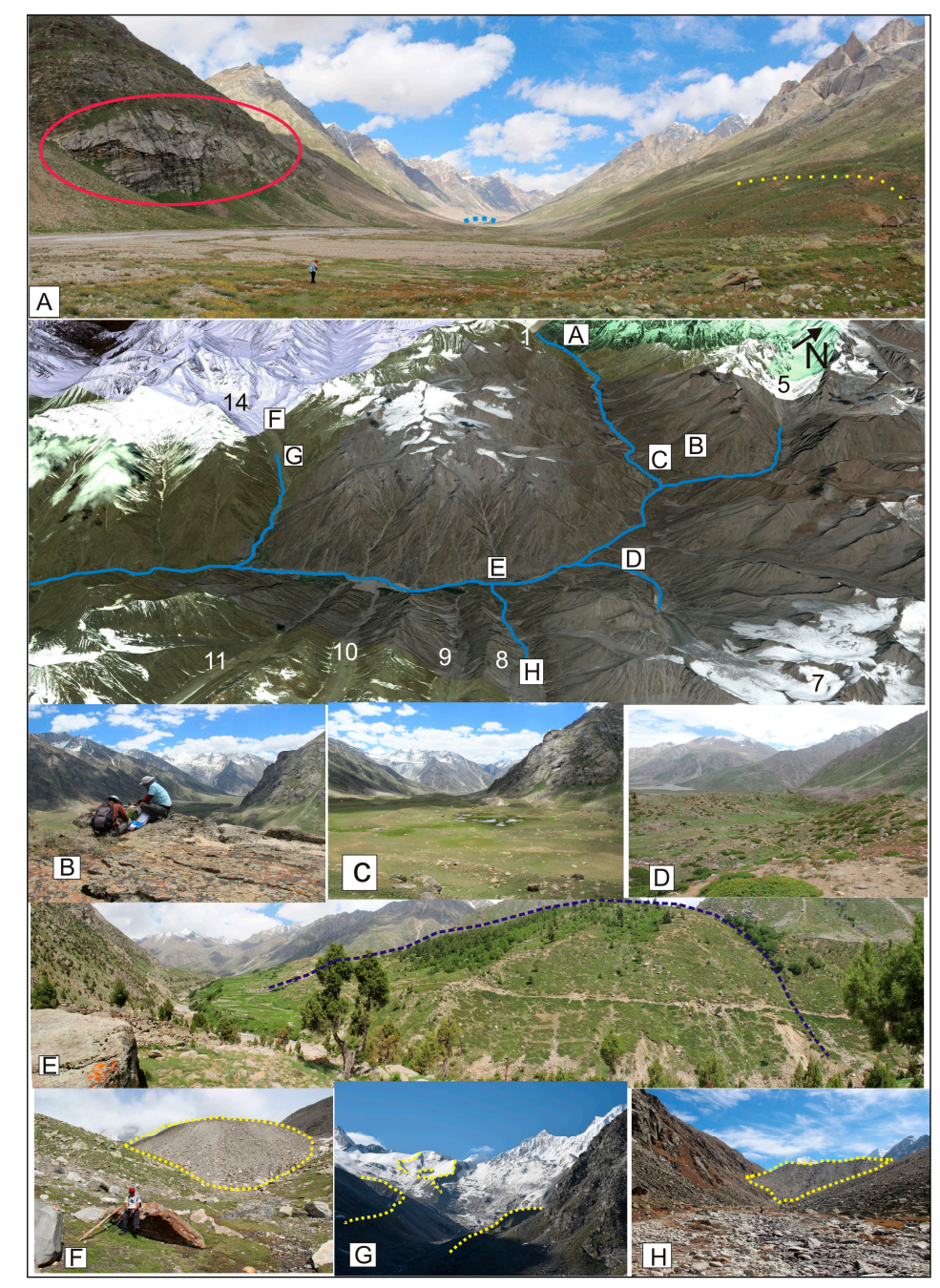

Figure 5. Location of landforms associated with various glacial episodes in the Miyar basin (glacier numbers are marked in correspondence to Figure 2). (A) Wide glacial trough with truncated spurs (marked with ellipse) marking the local LGM; the blue dashed line marks the contemporary terminus, while the yellow dotted line represents the second glacial stage. (B) Glacially eroded bench at Gumba (200m above the present valley floor) overridden by MR-I stage or the local LGM. (C-E) Lateral moraines, hummocks, and end-moraine dumps deposited during an early Holocene glacial expansion, i.e., the KH-II stage. (F-H) Fresh deposits of the Menthosa advance (M-III). 


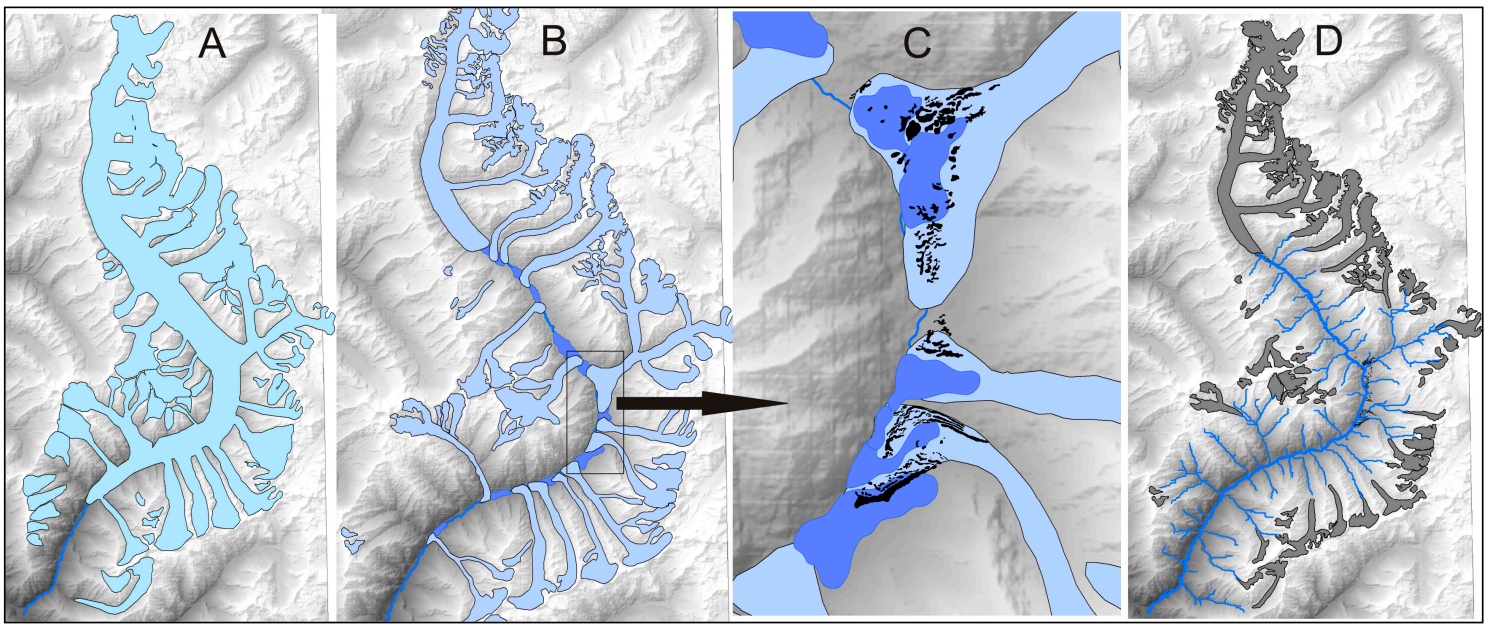

Figure 6. The Miyar basin during various stages of glaciation, and the sequential evolution of major landforms. (A) MR-I glacial stage and the evolution of a glacial trough. Sedimentary records for this stage could not be found, which indicates the age. (B) Expansion of glaciers during the KH-II glacial stage, and blocking of the major river at several places resulting in the formation of glacial lakes. (C) A section from map-B covering the area of Gumba and Tharang terminuses shows the decaying stage of KH-II and the evolution of various interwoven sets of lateral and hummocky moraines. This also resulted in the formation of ice-dammed and moraine-dammed lakes, and provided the opportunity for lacustrine plains to be formed. (D) Present glaciation.

\subsection{Miyar Stage $(M R-I)$}

The oldest and largest glacial event, termed here as the Miyar stage (MR-I), has been established on the basis of trimlines and truncated spurs (Figure 3A). The maximum advance of this stage has been traced down to village Karpat, nearly $35 \mathrm{~km}$ from the present snout of the Miyar Glacier. Major tributary glaciers coalesced to form an extensive trunk glacier. Most of the landform records of this major event have been obliterated due to later slope and possibly tectonic reworking; therefore, this episode could not be dated with OSL techniques. Eye-catching evidence for this stage is a glacially eroded bench nearly $200 \mathrm{~m}$ above the present valley floor at Gumba (Figure 5B).

\subsection{Khanjar Stage (KH-II)}

The second major glacier advance has been established on the basis of vast and widespread occurrence of lateral moraines and end moraine complexes in almost every tributary valley (Figure 5C-E). Simple criteria of relative dating have been applied here to distinguish and name this stage, because its glacial landforms are inset within the larger framework of the U-shaped glacial trough from the Miyar stage. All major tributary glaciers advanced to block the main trunk valley, creating lacustrine fills at many junctions and changing the main valley profile. We name this episode as the Khanjar stage (KH-II) constrained within 8-6 ka, i.e., early Holocene comparable to the Shivling stage in Garhwal [68]. This advance was confined within 4-6 km from the contemporary glacier terminuses.

In the lower part of the basin, sharply crested lateral moraines of tributary glaciers descend from $\sim 4600$ to $\sim 3000 \mathrm{~m}$ a.s.l. within a short distance of $3.7-5.4 \mathrm{~km}$, controlled strongly by slope characteristics. Tributary valleys on the left bank in the lower basin (Tharang, Uldhampu, Khanjar, and Karpat) have the largest accumulation of end moraine complexes. Drumlins and hummocks have been found in a vast and nearly flat plain (lacustrine fill) at Thampatan at the confluence of the Miyar and Gumba streams. The long axes of these drumlins show NE-SW alignment when deposited by the Gumba Glacier, and further down valley E-W alignment when deposited by the Tarsalamu Glacier. Some drumlins from the Gumba Glacier are aligned N-S along the valley wall; this section has been put at $4.3 \pm 0.6 \mathrm{ka}$ (Figure 7). Field mapping between Gumba and Tarsalamu moraine complexes 
demonstrates the complexity of the landforms. The shape and orientation of the glacial deposits do not match those of true drumlins, with a few exceptions. These mounds more closely resemble hummocky moraines. We think that these hummocks and drumlins formed between $6.6 \pm 1.0$ and $4.3 \pm 0.6 \mathrm{ka}$ during a waning phase of the glaciers.

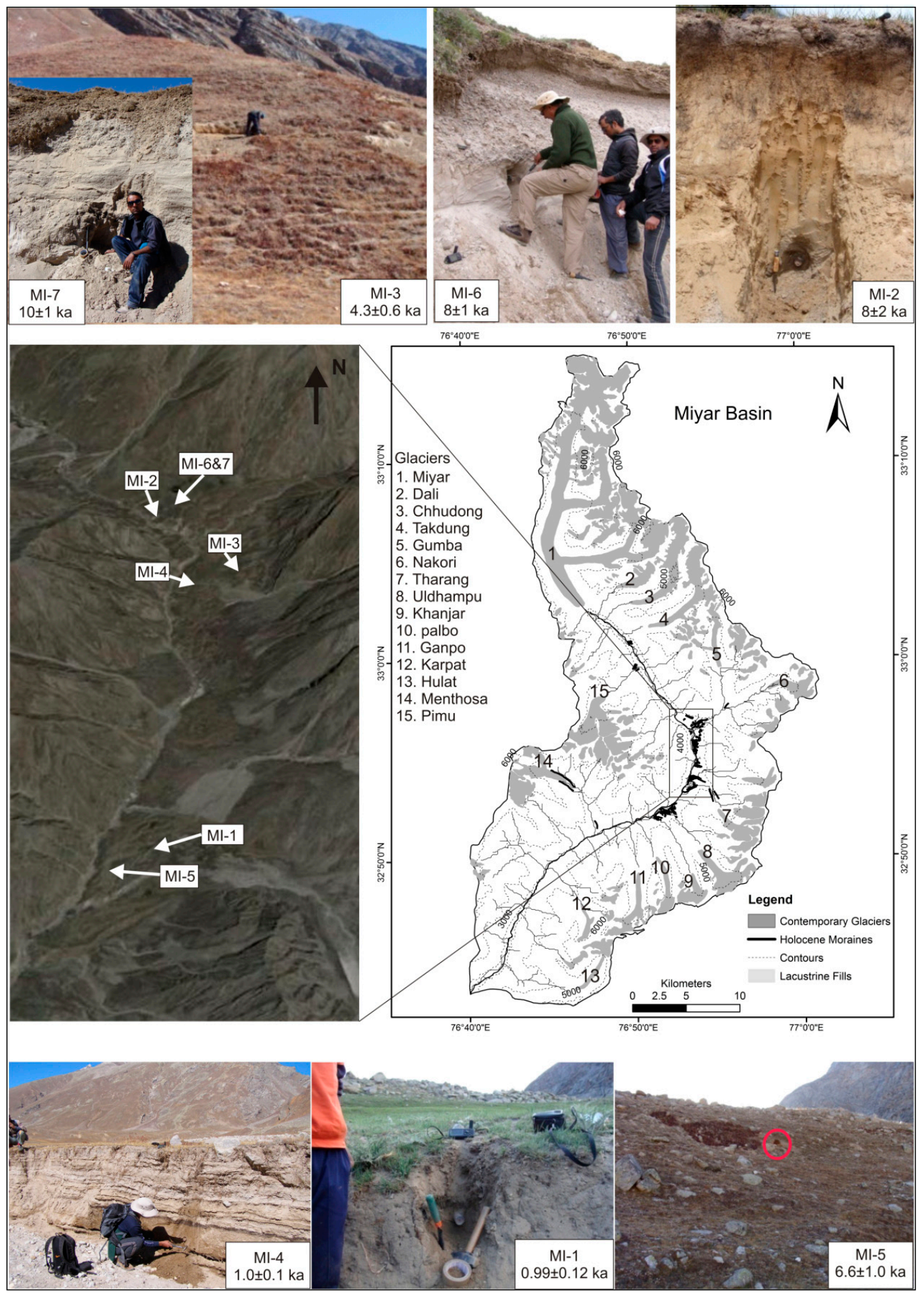

Figure 7. OSL sample collection (and ages) in the Miyar basin. A total of seven samples were collected (MI-1 to MI-7). 


\subsection{Menthosa Advance (M-III)}

A small yet significant advance of glaciers marked by sharp crested moraine ridges and freshly deposited terminal moraines within the limit of $1.5 \mathrm{~km}$ from contemporary snouts is named the Menthosa advance (M-III) (Figure 3F-H). Though this event of glacier advance has not been dated, we observed the existence of ancient human settlements near the Tharang end moraine complex and put them into the Little Ice Age (LIA) period [69]: three agricultural ruin sites with irrigation systems existed between 1168 and $1726 \mathrm{AD}\left({ }^{14} \mathrm{C}\right.$ dates). Therefore, we believe that this advance may be a historical episode related to 200-250 years BP termed Bhujbas in Gangotri [68] and Sonapani-1 elsewhere in Lahaul $[24,70]$. This glacial episode was associated with the strengthened Indian Summer Monsoon around the 18th century [71]. In terms of modern terminus elevations, the Miyar Glacier is located at the lowest elevation, terminating at $\sim 4060 \mathrm{~m}$ a.s.l., followed by the Chhudong Glacier at $\sim 4343$ $\mathrm{m}$ a.s.l. However, during the historical advance, the glacier with the lowest terminus elevation was the Chhudong at $\sim 3931 \mathrm{~m}$ a.s.l., followed by the Tharang ( 3939 $\mathrm{m}$ a.s.l.) and the Miyar ( 3973 $\mathrm{m}$ a.s.l.). Such varied response again suggests topographic controls on glacier advance, as large glaciers like Miyar show relatively limited changes in extent when compared to medium and small glaciers.

\subsection{Optical Chronology}

The OSL samples were collected from the ice contact sediments found within the lateral moraine, exposed sections of lacustrine fills, and drumlins (Table 2). Two samples were collected from the Tharang end moraine complex (MI-1 and MI-5). Sample MI-1 was from a sand lens at $0.7 \mathrm{~m}$ below the top of the lacustrine fill, while sample MI- 5 was collected from an exposed section of terminal moraine $3.4 \mathrm{~m}$ below the top. Sample MI-1 from lacustrine sediment dates to $992 \pm 120$ years BP, whereas sample MI-5 from the terminal moraine dates to $6.6 \pm 1.0 \mathrm{ka}$ BP.

Table 2. OSL characteristics and ages of samples.

\begin{tabular}{cccccc}
\hline Sample ID & U (ppm) & Th $(\mathbf{p p m})$ & K (\%) & Dose Rate gy/ka & Age (ka) \\
\hline MI-1 & 5.9 & 21.6 & 2.9 & $5.0 \pm 0.5$ & $0.99 \pm 0.12$ \\
MI-2 & 4.7 & 38.8 & 2.8 & $5.7 \pm 0.5$ & $8 \pm 2$ \\
MI-3 & $6.73 \pm 0.1$ & $19.1 \pm 0.2$ & $2.40 \pm 0.02$ & $4.6 \pm 0.6$ & $4.3 \pm 0.6$ \\
MI-4 & $5.45 \pm 0.05$ & $19.9 \pm 0.3$ & $2.93 \pm 0.02$ & $4.9 \pm 0.6$ & $1.0 \pm 0.1$ \\
MI-5 & $9.63 \pm 0.1$ & $25.6 \pm 0.2$ & $3.43 \pm 0.03$ & $6.5 \pm 1.0$ & $6.6 \pm 1.0$ \\
MI-6 & 6.31 & 2.97 & 2.97 & $5.8 \pm 0.4$ & $8 \pm 1$ \\
MI-7 & 6.4 & 2.89 & 2.89 & $5.7 \pm 0.4$ & $10 \pm 1$ \\
\hline
\end{tabular}

The geomorphological map of the Tharang end-moraine complex exhibits the recessional history of Tharang Glacier and indicates towards the glacial history of the basin during the Holocene (Figure 8). It presents a spectacular arrangement of various landforms, and the style and fashion of glacier expansion and recession can be interpreted. There is a set of outer lateral moraines on both sides of the Tharang stream, enclosing the whole area and providing the condition for lacustrine filling. There are three more parallel ridges of lateral moraines on right side of the Tharang stream. On the left side, on the other hand, there are discontinuous and broken ridges of lateral moraines often merged with hummocks, except in case of the outer most. This suggests continuous recession of glaciers and, thus, the formation of the recessional moraines since $\sim 4 \mathrm{ka} \mathrm{BP}$, which is the age given by one sample from a drumlin (see below). 


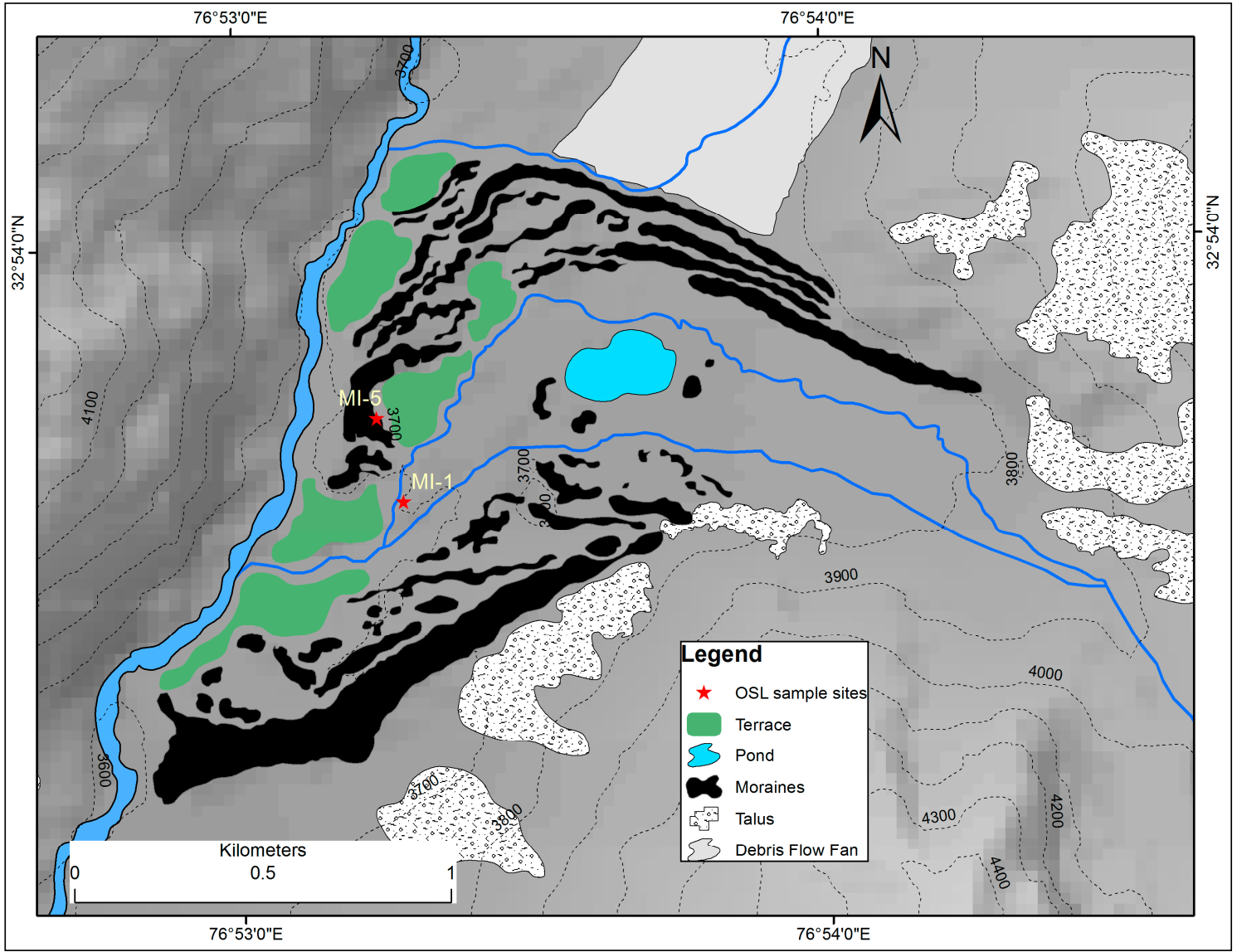

Figure 8. The geomorphological map of the Tharang end moraine complex shows the recessional nature of parallel moraine sequences. The MI-1 (lacustrine) and MI-5 (terminal moraine) OSL sample locations are also shown. Moraines are represented as polygon features to highlight the exact areal coverage and to avoid confusion about various types of moraines.

OSL samples MI-2, MI-6 and MI-7 were collected from a section of lacustrine fill at Gumba upstream from the confluence of the Gumba stream and the main Miyar River (Figure 9). These samples were taken in $3.3 \mathrm{~m}, 3.1 \mathrm{~m}$ and $3.5 \mathrm{~m}$ below the top, respectively, and produced ages of $8 \pm 2 \mathrm{ka}$, $8 \pm 1 \mathrm{ka}$ and $10 \pm 1 \mathrm{ka}$, respectively. The dates suggest that Gumba Glacier advanced into the trunk valley at $\sim 10 \mathrm{ka} B P$ and blocked the flow of major rivers, resulting in the formation of a lake and the deposition of lacustrine sediments. This lacustrine fill that measures tens of meters in thickness modified the landscape to a great extent, leaving behind the remains of lateral moraines, hummocks, and terraces. 


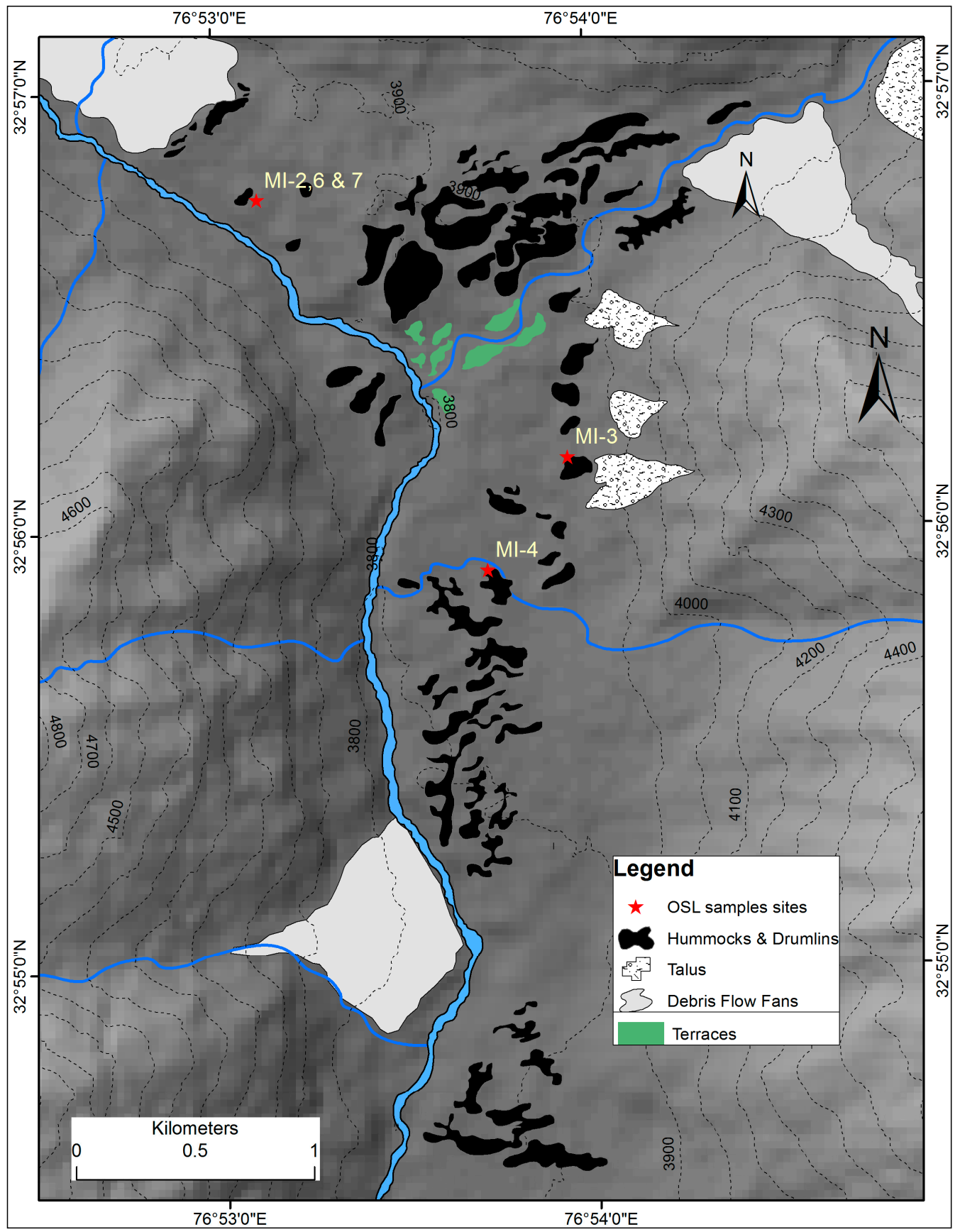

Figure 9. The geomorphological map of the Gumba moraine complex show the location of OSL samples and widespread distribution of hummocks and drumlins. Samples MI-2, -6 and -7 are from lacustrine fill formed as a result of a blockage of the main stream by an advanced Gumba Glacier during the early Holocene.

The vast flat Thampatan plain, formed by lacustrine fill, exists on the left side of the Gumba stream. Drumlins and the remains of hummocks are dispersed throughout the plain (Figure 10). One exposed part of a drumlin dates to $4.3 \pm 0.6 \mathrm{ka} \mathrm{BP}$ (MI-3, taken $1.4 \mathrm{~m}$ below the top), which possibly indicates the start of deglaciation. The Thampatan plain was enclosed and blocked by moraines, drumlins and hummocks until to as recently as $\sim 1000$ years BP. This is evident from the age of $1.0 \pm 0.1 \mathrm{ka}$ of the lacustrine deposit (MI-4, taken $1.5 \mathrm{~m}$ below the top). 


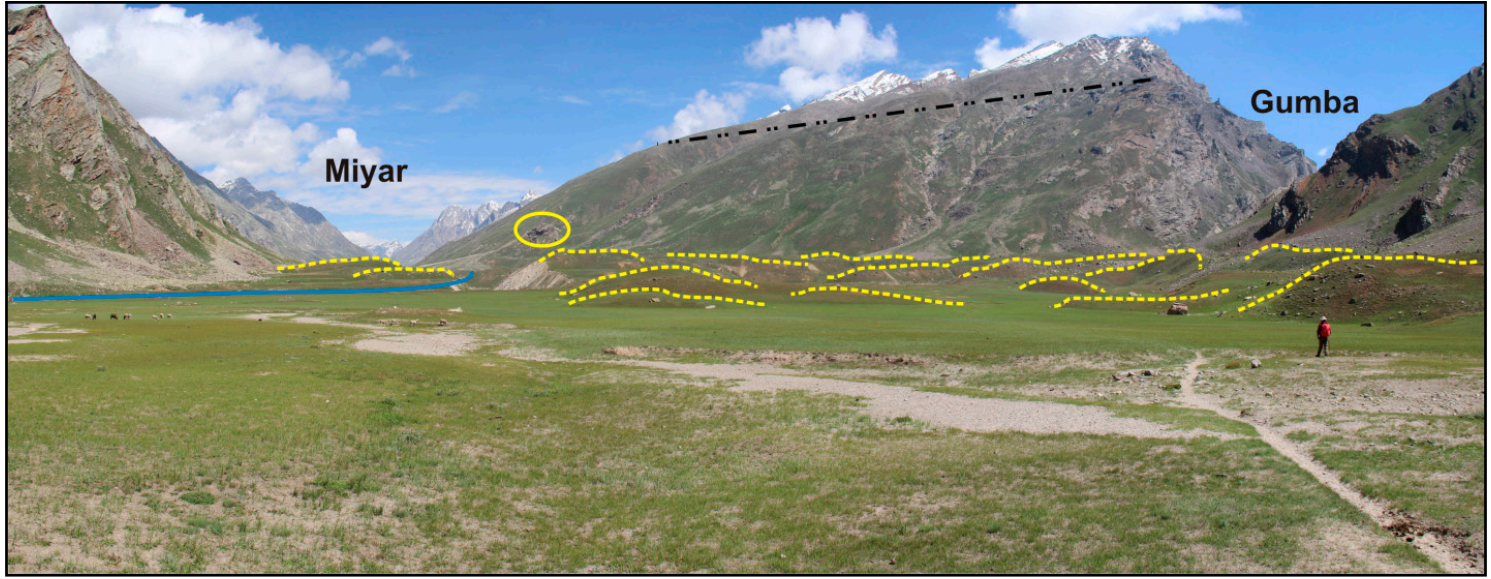

Figure 10. The Thampatan plain formed as a result of lacustrine sedimentation downstream from the confluence of the Gumba stream and the main Miyar River. Numerous drumlins formed here (marked by the yellow dotted lines) during a deglaciation phase. One such drumlin dates to $4.3 \pm 0.6 \mathrm{ka}$. A glacially eroded bench from the MR-I stage can be seen in the background (encircled). The MR-I stage trimline is marked by the black dotted line. The contemporary Miyar River is not visible due to the thick lacustrine fill; it is marked by a blue line. (View looking upstream.)

\subsection{Paleotemperature and Ice Volume Estimation}

The ELAs for the present glaciers range from 4911-5317 m a.s.l., with a mean of $5075 \mathrm{~m}$ a.s.l. (Table 3). The thickness of the former glacier ice, inferred from difference between the present valley floor and the edge of the polished surface of truncated spurs, was $\sim 500 \mathrm{~m}$. The mean ELA during the early Holocene was $4652 \mathrm{~m}$ a.s.l., with a $\triangle$ ELA of $423 \mathrm{~m}$ between then and today. Although the relationship between glacier area changes and climate change is a challenging issue in paleoclimatology, climate change has been often estimated using $\triangle$ ELA [36] that is influenced both by changes in temperature and precipitation. However, temperature estimates are rather simple, because of the assumption that the temperature changes follow an average environmental lapse rate in the atmosphere [12,72]. Nevertheless, it is difficult to quantify the change in climate that caused fluctuation in glaciers in the Himalayas with varying topography and climate characteristics. This is because of a poorly constrained relationship between the meteorological and glacier conditions and the absence of continuous meteorological records. Thus, the $\triangle$ ELA obtained between different glacial stages is converted to relative temperature decline by multiplying the $\Delta$ ELA values by the widely used mean air temperature lapse rate of $6.5^{\circ} \mathrm{C} / \mathrm{km}$, as has been done for Chhota-Shigri Glacier in the Lahaul Himalaya [69]. For the Miyar basin, we put the temperature decline at $3.9^{\circ} \mathrm{C}$ for the local LGM, and at $2.7^{\circ} \mathrm{C}$ for the early Holocene (Table 4 ). 
Table 3. Altitudes of several characteristic locations at glaciers in the Miyar basin during the local LGM, early Holocene, and the present.

\begin{tabular}{|c|c|c|c|c|c|c|c|c|c|c|}
\hline $\begin{array}{l}\text { Glacier } \\
\text { Name }\end{array}$ & Headwall & $\begin{array}{c}\text { Local LGM } \\
\text { Termini }\end{array}$ & $\begin{array}{c}\text { Holocene } \\
\text { Termini }\end{array}$ & PresentTermini & $\begin{array}{l}\text { ELA Local } \\
\text { LGM }\end{array}$ & $\begin{array}{c}\text { Holocene } \\
\text { ELA }\end{array}$ & Present ELA & $\begin{array}{c}\Delta \text { ELA } \\
\text { (Holocene } \\
\text { to Local } \\
\text { LGM) }\end{array}$ & $\begin{array}{c}\Delta E L A \\
\text { (Present to } \\
\text { Local LGM) }\end{array}$ & $\begin{array}{c}\Delta \text { ELA } \\
\text { (Present to } \\
\text { Holocene) }\end{array}$ \\
\hline Miyar & 5924 & 3063 & 3974 & 4046 & 4469 & 4949 & 4985 & 456 & 492 & 36 \\
\hline Dali & 5756 & 3063 & 3963 & 4878 & - & 4860 & 5317 & 450 & 908 & 458 \\
\hline Chhudong & 5746 & 3063 & 3917 & 4315 & - & 4832 & 5031 & 427 & 626 & 199 \\
\hline Takdung & 5725 & 3063 & 3951 & 4536 & - & 4838 & 5131 & 444 & 737 & 293 \\
\hline Gumba & 5703 & 3063 & 3836 & 4410 & - & 4770 & 5057 & 387 & 674 & 287 \\
\hline Tharang & 5845 & 3063 & 3608 & 4527 & - & 4727 & 5186 & 273 & 732 & 460 \\
\hline Uldhampu & 5334 & 3063 & 3488 & 4507 & - & 4411 & 4921 & 213 & 722 & 510 \\
\hline Khanjar & 5569 & 3063 & 3442 & 4586 & - & 4506 & 5078 & 190 & 762 & 572 \\
\hline Palbo & 5498 & 3063 & 3455 & 4590 & - & 4477 & 5044 & 196 & 764 & 568 \\
\hline Gangpo & 5493 & 3063 & 3317 & 4416 & - & 4405 & 4955 & 127 & 677 & 550 \\
\hline Karpat & 5571 & 3063 & 3017 & 4250 & - & 4294 & 4911 & 23 & 594 & 617 \\
\hline Menthosha & 5774 & 3063 & 3299 & 4396 & - & 4537 & 5085 & 118 & 667 & 549 \\
\hline \multirow[t]{2}{*}{ Pimu } & 5778 & 3063 & 3900 & 4578 & - & 4839 & 5178 & 419 & 758 & 339 \\
\hline & & (Mean value) & & & 4469 & 4652 & 5075 & 183 & 606 & 423 \\
\hline
\end{tabular}

Table 4. Ice thickness, ice volume, and paleotemperature estimations for the Miyar basin based on ELA.

\begin{tabular}{|c|c|c|c|c|c|c|c|c|}
\hline Stage & $\begin{array}{l}\text { Terminus } \\
\text { (m a.s.l.) }\end{array}$ & $\begin{array}{c}\text { Headwall } \\
\text { (m a.s.l.) }\end{array}$ & Area $\left(\mathrm{km}^{2}\right)$ & ELA (m. a.s.1.) & Ice Thickness (m) & Volume $\left(\mathbf{k m}^{3}\right)$ & $\begin{array}{l}\triangle \text { ELA (From } \\
\text { Present) }\end{array}$ & $\begin{array}{c}\text { Temperature } \\
\text { Decline }\left({ }^{\circ} \mathrm{C}\right) \\
\text { (From Present) }\end{array}$ \\
\hline Local LGM & 3063 & 5924 & 530 & $4469 \pm 124$ & 62.62 & 33.19 & 606 & 3.9 \\
\hline Holocene & - & - & 282.5 & $4652 \pm 137$ & 92.00 & 25.99 & 423 & 2.7 \\
\hline Present & - & - & 88.87 & $5075 \pm 137$ & 119.05 & 10.58 & $\mathrm{~N} / \mathrm{A}$ & $\mathrm{N} / \mathrm{A}$ \\
\hline
\end{tabular}




\section{Discussion}

The glacial chronology presented here for the Miyar basin in the Lahaul Himalaya allows us to understand the pattern of landform evolution and associated climate variability during the late Pleistocene period. However, the availability of OSL samples from the studied moraines and glacial stage/episodes is limited, which complicates the assessment of the precise timing of moraine formation. Nevertheless, great care was taken in choosing samples and further correlation with adjoining valleys, providing confidence in our sampling technique and the obtained results. Confidence in the validity of our data is further strengthened by reasonable agreement with existing chronologies from the adjoining Himalaya region, e.g., Lahaul Himalaya [25], Tons and Thangi valleys [12,25,44], Gangotri Glacier [19,68], eastern Nanda Devi region [73], and the Central Himalaya [14].

The early Holocene glacier advance (KH-II) in the Miyar basin was reconstructed with the help of OSL dates and geomorphological evidence. The expansion of tributary glaciers into the main valley resulted in several blockages of the Miyar River, which resulted in the formation of larger lacustrine sediments. OSL samples from the Gumba lacustrine fill ( $8 \pm 2 \mathrm{ka}, 8 \pm 1 \mathrm{ka}$, and $10 \pm 1 \mathrm{ka})$ suggested that the maximum extent of the Gumba Glacier occurred 10-8 ka BP. We assign these advances to the early Holocene intensification of the ISM [14,74], which is also supported by radiocarbon dates obtained from peat bog at Chandratal, indicating that the peat growth began $9160 \pm 70$ years BP [24], thus inferring an increase in either temperature or precipitation in the Lahaul Himalaya during the early Holocene. However, this idea of increased temperatures in the early Holocene times contradicts the idea that this period was a time of extensive glaciation in the Miyar basin. An early Holocene glacier stage in Lahaul Himalaya is also supported by the Cosmogenic Radio Nuclide (CRN) surface exposure dates from nearby valleys, for example, Rape $(9.0 \pm 0.1 \mathrm{ka})$, Sissu (9.5 $\pm 0.5 \mathrm{ka})$, Batal (11.4 $\pm 0.3 \mathrm{ka}$, and $12.0 \pm 0.1$ ) [75]. Additionally, for the Sarchu Plains an early Holocene glacial advance has been put at $8.2 \mathrm{ka}$ based on optical dating [76]. Therefore, our study supports the view that during the early Holocene the Lahaul experienced increased precipitation rather than increased temperatures.

Moreover, it is suggested that the most extensive glacial advances in the Himalaya and Tibetan region generally occurred during the early Holocene, between $11.5 \mathrm{ka}$ and $\sim 8.0 \mathrm{ka}[5,14,25,73,75,77]$, and that this was related to both an increase in monsoon precipitation [78] and lower temperatures [23]. However, the extent of glaciation and ELA depressions during the early Holocene vary considerably between regions, and a complex pattern of glaciation has been observed, with some regions having evidence for glacial advances at times, whereas others showed no advances $[14,19,21,74]$.

Increasing concentration of anti-ferromagnetic minerals from $\sim 10,398-5770$ cal. years BP in the peat-lake deposits from a post-glacial lake in the adjoining Chandra Valley of the Lahaul Himalaya suggest an overall increased ISM intensity during early to mid-Holocene, which is well correlated with the $\delta^{18} \mathrm{O}$ record of the ISM-influenced Dongge Cave from $\sim 11,500-6000$ cal. years BP [79]. Thus, the second glacial event (KH-II) occurred during the cold Bond event-7 and sustained beyond the early Holocene climatic optimum due to ice-albedo feedback mechanism; an increase in precipitation during the early Holocene is supposed to have lowered the summer temperature due to an increase in the cloudiness (an increase in albedo) and evaporating cooling [23,53].

The Menthosa advance terminates in the vicinity of the present glaciers and is undated due to unavailability of suitable materials. Based on its extent, moraine morphology, steep crests without vegetation cover, and limited extent from the present snouts, it is interpreted as being a very recent advance. Our assumption of a stable/semi-stable terminus position since the last 1000 years is supported by the fact that such places (Tharang end moraine complex) were inhabited and had settled agriculture, as suggested by the irrigated abandoned fields and ruins within $3 \mathrm{~km}$ of the present terminus. Ruins date to AD 1168-1726 [69], covering the whole LIA period and located on the KH-II stage end moraine complex. In addition, there are other proxies that reveal the paleoclimatic conditions across the Indian subcontinent. A weak monsoon has been suggested for the LIA based on bioturbated sediments in the Arabian Sea [80]. Based on tree ring data, it is suggested that drought conditions were prevalent in the Western Himalaya during the 14th to 16th centuries, and high precipitation occurred 
during the 18th to 19th centuries [81]. Calibrated speleothem oxygen isotope records from central and northeast Indian caves suggested weak monsoon (break-dominated) from AD 1400 to 1700 and active monsoon (active-dominated) from AD 1700 to 2007 [82]. However, based on the deposition of calcite at Panigarh cave, cooler and wetter conditions have been suggested for the LIA (AD 1400-1900), and drier and warmer conditions during the periods from AD 1250-1480 and after AD 1900 [83]. In view of the aforementioned studies, it is suggested that any generalization of climate change based on case studies should be avoided.

The oldest glacial episode in the basin (though undated) considerably predates the global LGM given the $\triangle$ ELA of $606 \mathrm{~m}$ compared to the present ELA (Table 3, Figure 2B). A similar $\triangle$ ELA $(640 \mathrm{~m})$ has been calculated for the local LGM of the Garhwal Himalaya, i.e., the Bhagirathi stage at $63 \mathrm{ka}$ [68]. The MR-I stage is termed here as local LGM as the glaciers in the Himalayan region advanced and receded asynchronously with those in other parts of the Northern Hemisphere $[4,68,84]$, reaching at maximum expansion during the Marine Isotopic Stage-3 (MIS-3) due to enhanced moisture conditions [4,77,84-86]. Additionally, evidence from ice cores also suggested that glaciation and deglaciation in lower latitudes are largely asynchronous with high-latitude glaciation and deglaciation [31,87]. However, a controversy appeared regarding the response of Himalayan glaciers at the time of the global LGM (18-24 ka). There is a conspicuous distinction of style and timing of glaciation in westerlies-dominated arid/semi-arid parts of western Himalaya and the monsoon-dominated humid regions of central and eastern Himalaya. Glaciers in humid areas advanced due to changes in precipitation, whereas glaciers in more arid areas are temperature-driven and advanced synchronously with the northern hemisphere ice sheets [75]. Glacial stages in semi-arid western Himalaya-Tibet orogen, which are older than $21 \mathrm{ka}$, are found to be more extensive and correlate with a stronger monsoon, whereas those around 21 ka or younger broadly correlate with global ice volume given by marine Oxygen Isotope Stages, and northern hemisphere climatic events generally controlled by Westerlies [74]. Based on new ${ }^{10} \mathrm{Be}$-ages, it has been suggested that the timing of glaciation in the SW Garhwal Himalaya is correlated with both periods of strong monsoons and northern hemisphere events throughout the entire chronologic range [14]. Recent studies suggested that the monsoon-dominated central Himalaya responded considerably to the global LGM despite decreased monsoon and to the combination of stronger mid-latitude Westerlies and lowered temperatures $[12,44,88,89]$.

In contrast to older studies, more recent studies on glacial chronology from the Lahaul region have suggested considerable glacial expansion at the time of the global LGM [76,90]. However, signatures of glacial episodes between MR-I and KH-II are completely missing in the Miyar basin, and the MR-I stage might be related to the Chandra stage proposed earlier in the region given the magnitude of glacier expansion [24,70]. However, in our study no absolute dates have been assigned to the Chandra stage. A higher age of the Chandra stage, however, can be assumed based on the age of subsequent stages, i.e., Batal $(43.4 \pm 10.3 \mathrm{ka})$ and Kulti $(36.9 \pm 8.4 \mathrm{ka})$ in the Lahaul Himalaya [24,25]. The oldest glacial stage in the Himalaya orogen in the Ladakh range has been described as being older than 430 ka [91] based on Terrestrial Cosmogenic Nuclide (TCN) surface exposure dating. Further east, in the monsoon-dominated Rongbuk Valley in the Mount Everest region, the oldest glacial stage has been dated to be older than $330 \mathrm{ka}$ [11]. North of our study area, in eastern Ladakh, pollen and ${ }^{14} \mathrm{C}$ analyses provided evidence of a sequence of changes in vegetation cover in response to climate, suggesting that the period from 22 to $18 \mathrm{ka}$ was a warmer phase for profuse growth of juniper in the region and consequently glaciation ceased at the time of the global LGM [92]. Thus, leaving the debate open, we must stress the need for more Quaternary studies that include absolute chronologies in order to understand the mechanism of glaciation in these parts of the Himalayas.

\section{Conclusions}

The present study provides valuable insight into the glaciation of the westerlies-dominated Miyar basin in the Lahual Himalaya. Our study identified three major glaciation events of decreasing magnitude. The oldest Miyar stage (MR-I) is assigned to pre-gLGM times based on geomorphological 
evidence. The following Khanjar stage (KH-II) occurred between $10 \pm 1$ and $6.6 \pm 1.0 \mathrm{ka}$, which corresponds to the early Holocene advance following the Younger Dryas cooling event. The (undated) Menthosa advance (M-III) stage could be related to the 18th-century cooling event. The oldest glaciation (MR-I) is identified as the local LGM, which considerably predates the global LGM. For the period of the global LGM (18-24 ka), there is no evidence of glacier expansion in the basin. All glaciers in the basin expanded by $\sim 3-7 \mathrm{~km}$ between 10 and $8 \mathrm{ka}$. We suggest that the early Holocene expansions of the smaller tributary glaciers happened in response to increased monsoon precipitation during the early Holocene, and may have resulted in only a smaller advance of the Miyar Glacier, which has a longer response time. Deglaciation following the KH-II stage expansion was extremely gradual, leading to drumlin field formation at Thampatan. We did not observe any glacier expansion in the basin corresponding to the LIA period. However, sharp crested moraines and frontal dumps of comparatively recent origin have been found in the tributary valleys of the Menthosa, Uldhampu, and Tharang glaciers. We have suggested that this minor advance might be from the 18th century, and termed it the Menthosa Advance.

Acknowledgments: We are thankful to the Space Application Centre (SAC) Ahmedabad and the Department of Science and Technology (DST) for providing funding for this study. We acknowledge the suggestions and comments received from V.K. Raina and Lewis Owen when reviewing an earlier draft of the manuscript. We are also grateful to Jawaharlal Nehru University, New Delhi for providing the necessary time, space, and logistics.

Author Contributions: S.D., M.C.S., A. and I.M.B. conceived and designed the work; S.D., M.C.S., R.S., P.C. and I.S. performed the field work; N.J. and P.S. performed the laboratory work and analyzed the data; S.D., M.C.S., R.S. and P.C. wrote the paper.

Conflicts of Interest: The authors declare no conflict of interest.

\section{References}

1. Molnar, P.; England, P. Late Cenozoic uplift of mountain ranges and global climate change: Chicken or egg? Nature 1990, 346, 29-34. [CrossRef]

2. Ruddiman, W.F.; Kutzbach, J.E. Plateau uplift and climatic-change. Sci. Am. 1991, 264, 66-75. [CrossRef]

3. Prell, W.L.; Kutzbach, J.E. Sensitivity of the Indian monsoon to forcing parameters and implications for its evolution. Nature 1992, 360, 647-652. [CrossRef]

4. Benn, D.I.; Owen, L.A. The role of the Indian summer monsoon and the mid-latitude westerlies in Himalayan glaciation: Review and speculative discussion. J. Geol. Soc. Lond. 1998, 155, 353-363. [CrossRef]

5. Owen, L.A.; Gualtieri, L.; Finkel, R.C.; Caffee, M.W.; Benn, D.I.; Sharma, M.C. Cosmogenic radionuclide dating of glacial landforms in the Lahul Himalaya, northern India: Defining the timing of Late Quaternary glaciation. J. Quat. Sci. 2002, 17, 279-281. [CrossRef]

6. Raymo, M.E.; Ruddiman, W.F. Tectonic forcing of late Cenozoic climate. Nature 1992, 359, 117-122. [CrossRef]

7. Brozovic, N.; Burbank, D.W.; Meigs, A.J. Climatic Limits on Landscape Development in the Northwestern Himalaya. Science 1997, 276, 571-574. [CrossRef]

8. Zeitler, P.K.; Meltzer, A.S.; Koons, P.O.; Craw, D.; Hallet, B.; Chamberlain, C.P.; Kidd, W.S.F.; Park, S.K.; Seeber, L.; Bishop, M.; et al. Erosion, Himalayan geodynamics, and the geomorphology of metamorphism. GSA Today 2001, 11, 4-9. [CrossRef]

9. Norton, K.P.; Abbühl, L.M.; Schlunegger, F. Glacial conditioning as an erosional driving force in the Central Alps. Geology 2010, 38, 655-658. [CrossRef]

10. Willett, S.D. Erosion on a line. Tectonophysics 2010, 484, 168-180. [CrossRef]

11. Owen, L.A. Latest Pleistocene and Holocene glacier fluctuations in the Himalaya and Tibet. Quat. Sci. Rev. 2009, 28, 2150-2164. [CrossRef]

12. Scherler, D.; Bookhagen, B.; Strecker, M.R.; von Blanckenburg, F.; Rood, D. Timing and extent of late Quaternary glaciation in the western Himalaya constrained by ${ }^{10} \mathrm{Be}$ moraine dating in Garhwal, India. Quat. Sci. Rev. 2010, 29, 815-831. [CrossRef]

13. Owen, L.A.; Dortch, J.M. Nature and timing of Quaternary glaciation in the Himalayan-Tibetan orogen. Quat. Sci. Rev. 2014, 88, 14-54. [CrossRef] 
14. Murari, M.K.; Owen, L.A.; Dortch, J.M.; Caffee, M.W.; Dietsch, C.; Fuchs, M.; Haneberg, W.C.; Sharma, M.C.; Townsend-Small, A. Timing and climatic drivers for glaciation across monsoon-influenced regions of the Himalayan-Tibetan orogen. Quat. Sci. Rev. 2014, 88, 159-182. [CrossRef]

15. Gillespie, A.; Molnar, P. Asynchronous maximum advances of mountain and continental glaciers. Rev. Geophys. 1995, 33, 311. [CrossRef]

16. Owen, L.A.; Caffee, M.W.; Finkel, R.C.; Seong, Y.B. Quaternary glaciation of the Himalayan-Tibetan orogen. J. Quat. Sci. 2008, 23, 513-531. [CrossRef]

17. Lehmkuhl, F.; Owen, L.A.; Derbyshire, E. Late Quaternary Glacial History of Northeast Tibet. Quat. Proc. 1998, 6, 121-142.

18. Lehmkuhl, F.; Owen, L. Late Quaternary glaciation of Tibet and the bordering mountains: A review. Boreas 2005, 34, 87-100. [CrossRef]

19. Owen, L.A.; Benn, D.I. Equilibrium-line altitudes of the Last Glacial Maximum for the Himalaya and Tibet: an assessment and evaluation of results. Quat. Int. 2005, 138-139, 55-78. [CrossRef]

20. Böhner, J. General climatic controls and topoclimatic variations in Central and High Asia. Boreas 2006, 35, 279-295. [CrossRef]

21. Dortch, J.M.; Owen, L.A.; Schoenbohm, L.M.; Caffee, M.W. Asymmetrical erosion and morphological development of the central Ladakh Range, northern India. Geomorphology 2011, 135, 167-180. [CrossRef]

22. Zech, R.; Zech, M.; Kubik, P.W.; Kharki, K.; Zech, W. Deglaciation and landscape history around Annapurna, Nepal, based on 10Be surface exposure dating. Quat. Sci. Rev. 2009, 28, 1106-1118. [CrossRef]

23. Rupper, S.; Roe, G.; Gillespie, A. Spatial patterns of Holocene glacier advance and retreat in Central Asia. Quat. Res. 2009, 72, 337-346. [CrossRef]

24. Owen, L.A.; Bailey, R.M.; Rhodes, E.J.; Holloway, R. Style and timing of glaciation in the Lahul Himalaya, northern India: A framework for reconstructing late Quaternary palaeoclimatic change in the western Himalayas. J. Quat. Sci. 1997, 12, 83-109. [CrossRef]

25. Owen, L.A.; Gualtieri, L.Y.N.; Finkel, R.C.; Caffee, M.W.; Benn, D.I.; Sharma, M.C. Cosmogenic radionuclide dating of glacial landforms in the Lahul Himalaya, northern India: Defining the timing of Late Quaternary glaciation. J. Quat. Sci. 2001, 16, 555-563. [CrossRef]

26. Walker, J.D.; Martin, M.W.; Bowring, S.A.; Searle, M.P.; Waters, D.J.; Hodges, K.V. Metamorphism, Melting, and Extension: Age Constraints from the High Himalayan Slab of Southeast Zanskar and Northwest Lahaul. J. Geol. 1999, 107, 473-495. [CrossRef]

27. Vannay, J.-C.; Steck, A. Tectonic evolution of the High Himalaya in Upper Lahaul (NW Himalaya, India). Tectonics 1995, 14, 253-263. [CrossRef]

28. Robyr, M.; Vannay, J.-C.; Epard, J.-L.; Steck, A. Thrusting, extension, and doming during the polyphase tectonometamorphic evolution of the High Himalayan Crystalline Zone in NW India. J. Asian Earth Sci. 2002, 21, 221-239. [CrossRef]

29. Pognante, U.; Castelli, D.; Benna, P.; Genovese, G.; Oberli, F.; Meier, M.; Tonarini, S. The crystalline units of the High Himalayas in the Lahul-Zanskar region (northwest India): Metamorphic-tectonic history and geochronology of the collided and imbricated Indian plate. Geol. Mag. 1990, 127, 101. [CrossRef]

30. Pognante, U.; Lombardo, B. Metamorphic evolution of the High Himalayan Crystallines in SE Zanskar, India. J. Metamorph. Geol. 1989, 7, 9-17. [CrossRef]

31. Ali, S.N.; Biswas, R.H.; Shukla, A.D.; Juyal, N. Chronology and climatic implications of Late Quaternary glaciations in the Goriganga valley, central Himalaya, India. Quat. Sci. Rev. 2013, 73, 59-76. [CrossRef]

32. Fort, M. Geomorphological observations in the Ladakh area (Himalaya): Quaternary evolution and present dynamics. In Stratigraphy and Structure of Kashmir and Ladakh Himalaya; Gupta, V.J., Ed.; Hindustan Publishing: New Delhi, India, 1983; pp. 39-58.

33. McFadden, E.M.; Howat, I.M.; Joughin, I.; Smith, B.E.; Ahn, Y. Changes in the dynamics of marine terminating outlet glaciers in west Greenland (2000-2009). J. Geophys. Res. 2011, 116, F02022. [CrossRef]

34. Duncan, C.C.; Klein, A.J.; Masek, J.G.; Isacks, B.L. Comparison of Late Pleistocene and Modern Glacier Extents in Central Nepal Based on Digital Elevation Data and Satellite Imagery. Quat. Res. 1998, 49, $241-254$. [CrossRef]

35. Guo, W.; Liu, S.; Xu, J.; Wu, L.; Shangguan, D.; Yao, X.; Wei, J.; Bao, W.; Yu, P.; Liu, Q.; et al. The second Chinese glacier inventory: Data, methods and results. J. Glaciol. 2015, 61, 357-372. [CrossRef] 
36. Benn, D.I.; Owen, L.A.; Osmaston, H.A.; Seltzer, G.O.; Porter, S.C.; Mark, B. Reconstruction of equilibrium-line altitudes for tropical and sub-tropical glaciers. Quat. Int. 2005, 138-139, 8-21. [CrossRef]

37. Barr, I.D.; Clark, C.D. Late Quaternary glaciations in Far NE Russia; combining moraines, topography and chronology to assess regional and global glaciation synchrony. Quat. Sci. Rev. 2012, 53, 72-87. [CrossRef]

38. Meier, M.F.; Post, A.S. Recent variations in mass net budgets of glaciers in western North America. Int. Assoc. Sci. Hydrol. Publ. 1962, 58, 63-77.

39. Hawkins, F.F. Equilibrium-line altitudes and palaeoenvironments in the Merchants Bay area, Baffin Island, NWT, Canada. J. Glaciol. 1985, 31, 205-221. [CrossRef]

40. Porter, S.C. Equilibrium-line altitudes of late Quaternary glaciers in the Southern Alps, New Zealand. Quat. Res. 1975, 5, 27-47. [CrossRef]

41. Azam, M.F.; Ramanathan, A.; Wagnon, P.; Vincent, C.; Linda, A.; Berthier, E.; Sharma, P.; Mandal, A.; Angchuk, T.; Singh, V.B.; et al. Meteorological conditions, seasonal and annual mass balances of Chhota Shigri Glacier, western Himalaya, India. Ann. Glaciol. 2016. [CrossRef]

42. Dobhal, D.P.; Gergan, J.T.; Thayyen, R.J. Mass balance studies of the Dokriani glacier from 1992 to 2000, Garhwal Himalaya, India. Bull. Glaciol. Res. 2008, 25, 9-17.

43. Kulkarni, A.V. Mass balance of Himalayan glaciers using AAR and ELA methods. J. Glaciol. 1992, 38, $101-104$. [CrossRef]

44. Mehta, M.; Majeed, Z.; Dobhal, D.P.; Srivastava, P. Geomorphological evidences of post-LGM glacial advancements in the Himalaya: A study from Chorabari Glacier, Garhwal Himalaya, India. J. Earth Syst. Sci. 2012, 121, 149-163. [CrossRef]

45. Meierding, T.C. Late Pleistocene glacial equilibrium-line altitudes in the Colorado Front Range: A comparison of methods. Quat. Res. 1982, 18, 289-310. [CrossRef]

46. Burbank, D.W.; Fort, M. Bedrock control on glacial limits: Examples from the Ladakh and Zanskar ranges, north-western Himalaya, India. J. Glaciol. 1985, 31, 143-149. [CrossRef]

47. Clark, D.H.; Clark, M.M.; Gillespie, A.R. Debris-Covered Glaciers in the Sierra-Nevada, California, and Their Implications for Snowline Reconstructions. Quat. Res. 1994, 41, 139-153. [CrossRef]

48. Sissons, J.B. A Late-Glacial Ice Cap in the Central Grampians, Scotland. Trans. Inst. Br. Geogr. $1974,95$. [CrossRef]

49. Bashir, F.; Rasul, G. Estimation of Average Snow Cover over Northern Pakistan. Pak. J. Meteorol. 2010, 7, 63-69.

50. Siddiqui, M.A.; Maruthi, K.V. Detailed glaciological studies on Hamtah Glacier, Lahaul and Spiti District, H.P. Geol. Surv. India 2007, 140, 92-93.

51. Thayyen, R.J.; Gergan, J.T.; Dobhal, D.P. Lapse rate of slope air temperature in a Himalayan catchmentA study from Din Gad (Dokriani Glacier) basin, Garhwal Himalaya, India. Bull. Glaciol. Res. 2005, 22, $19-25$.

52. Pratap, B.; Dobhal, D.P.; Bhambri, R.; Mehta, M. Near-surface temperature lapse rate in Dokriani Glacier catchment, Garhwal Himalaya, India. Himal. Geol. 2013, 34, 183-186.

53. Sati, S.P.; Ali, S.N.; Rana, N.; Bhattacharya, F.; Bhushan, R.; Shukla, A.D.; Sundriyal, Y.; Juyal, N. Timing and extent of Holocene glaciations in the monsoon dominated Dunagiri valley (Bangni glacier), Central Himalaya, India. J. Asian Earth Sci. 2014, 91, 125-136. [CrossRef]

54. Frey, H.; Machguth, H.; Huss, M.; Huggel, C.; Bajracharya, S.; Bolch, T.; Kulkarni, A.; Linsbauer, A.; Salzmann, N.; Stoffel, M. Estimating the volume of glaciers in the Himalayan-Karakoram region using different methods. Cryosphere 2014, 8, 2313-2333. [CrossRef]

55. Haeberli, W.; Hoelzle, M. Application of inventory data for estimating characteristics of and regional climate-change effects on mountain glaciers: A pilot study with the European Alps. Ann. Glaciol. 1995, 21, 206-212. [CrossRef]

56. Richards, B.W.M. Luminescence dating of Quaternary sediments in the Himalaya and High Asia: A practical guide to its use and limitations for constraining the timing of glaciation. Quat. Int. 2000, 66, 49-61. [CrossRef]

57. Rhodes, E.J. Methodological considerations in the optical dating of quartz. Quat. Sci. Rev. 1988, 7, 395-400. [CrossRef]

58. Rhodes, E.J.; Pownall, L. Zeroing of the OSL signal in quartz from young glaciofluvial sediments. Radiat. Meas. 1994, 23, 581-585. [CrossRef]

59. Porat, N.; Botha, G. The luminescence chronology of dune development on the Maputaland coastal plain, southeast Africa. Quat. Sci. Rev. 2008, 27, 1024-1046. [CrossRef] 
60. Bøtter-Jensen, L.; Thomsen, K.J.; Jain, M. Review of optically stimulated luminescence (OSL) instrumental developments for retrospective dosimetry. Radiat. Meas. 2010, 45, 253-257. [CrossRef]

61. Duller, G.A.T. Assessing the error on equivalent dose estimates derived from single aliquot regenerative dose measurements. Anc. TL 2007, 25, 15-24.

62. Prescott, J.R.; Hutton, J.T. Cosmic ray contributions to dose rates for luminescence and ESR dating: Large depths and long-term time variations. Radiat. Meas. 1994, 23, 497-500. [CrossRef]

63. Murray, A.S.; Wintle, A.G. Luminescence dating of quartz using an improved single-aliquot regenerative-dose protocol. Radiat. Meas. 2000, 32, 57-73. [CrossRef]

64. Jacobs, Z.; Duller, G.A.T.; Wintle, A.G.; Henshilwood, C.S. Extending the chronology of deposits at Blombos Cave, South Africa, back to $140 \mathrm{ka}$ using optical dating of single and multiple grains of quartz. J. Hum. Evol. 2006, 51, 255-273. [CrossRef] [PubMed]

65. Jacobs, Z.; Wintle, A.G.; Duller, G.A.T.; Roberts, R.G.; Wadley, L. New ages for the post-Howiesons Poort, late and final Middle Stone Age at Sibudu, South Africa. J. Archaeol. Sci. 2008, 35, 1790-1807. [CrossRef]

66. Galbraith, R.F.; Roberts, R.G.; Laslett, G.M.; Yoshida, H.; Ollley, J.M. Optical dating of single and multiple grains of quartz from Jinmium rock shelter, northern Australia: Part I, experimental design and statistical models. Archaeometry 1999, 41, 339-364. [CrossRef]

67. Arnold, L.J.; Roberts, R.G. Stochastic modelling of multi-grain equivalent dose (De) distributions: Implications for OSL dating of sediment mixtures. Quat. Geochronol. 2009, 4, 204-230. [CrossRef]

68. Sharma, M.; Owen, L.A. Quaternary glacial history of NW Garhwal, Central Himalayas. Quat. Sci. Rev. 1996, 15, 335-365. [CrossRef]

69. Saini, R.; Sharma, M.C.; Deswal, S.; Barr, I.D.; Kumar, P. Glacio-archaeological evidence of warmer climate during the Little Ice Age in the Miyar basin, Lahul Himalaya, India. Clim. Past 2016. [CrossRef]

70. Owen, L.A.; Derbyshire, E.; Richardson, S.; Benn, D.I.; Evans, D.J.A.; Mitchell, W.A. The quaternary glacial history of the Lahul Himalaya, northern India. J. Quat. Sci. 1996, 11, 25-42. [CrossRef]

71. Thompson, L.G.; Yao, T.; Mosley-Thompson, E.; Davis, M.E.; Henderson, K.A.; Lin, P.-N.; Clemens, S.; Prell, W.; Muray, D.; Shimmield, G.; et al. A high-resolution millennial record of the south Asian monsoon from Himalayan ice cores. Science 2000, 289, 1916-1920. [CrossRef] [PubMed]

72. Porter, S.C. Snowline depression in the tropics during the last glaciation. Quat. Sci. Rev. 2001, 20, 1067-1091. [CrossRef]

73. Barnard, P.L.; Owen, L.A.; Sharma, M.C.; Finkel, R.C. Late Quaternary (Holocene) landscape evolution of a monsoon-influenced high Himalayan valley, Gori Ganga, Nanda Devi, NE Garhwal. Geomorphology 2004, 61, 91-110. [CrossRef]

74. Dortch, J.M.; Owen, L.A.; Caffee, M.W. Timing and climatic drivers for glaciation across semi-arid western Himalayan-Tibetan orogen. Quat. Sci. Rev. 2013, 78, 188-208. [CrossRef]

75. Owen, L.A.; Finkel, R.C.; Barnard, P.L.; Haizhou, M.; Asahi, K.; Caffee, M.W.; Derbyshire, E. Climatic and topographic controls on the style and timing of Late Quaternary glaciation throughout Tibet and the Himalaya defined by Be cosmogenic radionuclide surface exposure dating. Quat. Sci. Rev. 2005, 24, 1391-1411. [CrossRef]

76. Sharma, S.; Chand, P.; Bisht, P.; Shukla, A.D.; Bartarya, S.K.; Sundriyal, Y.P.; Juyal, N. Factors responsible for driving the glaciation in the Sarchu Plain, eastern Zanskar Himalaya, during the late Quaternary. J. Quat. Sci. 2016, 31, 495-511. [CrossRef]

77. Finkel, R.C.; Mass, A.; Livermore, L.; Owen, L.A.; Barnard, P.L.; Caffee, M.W. Beryllium-10 dating of Mount Everest moraines indicates a strong monsoon influence and glacial synchroneity throughout the Himalaya. Geology 2003, 6, 561-564. [CrossRef]

78. Bush, A. A comparison of simulated monsoon circulations and snow accumulation in Asia during the mid-Holocene and at the Last Glacial Maximum. Glob. Planet. Chang. 2002, 32, 331-347. [CrossRef]

79. Rawat, S.; Gupta, A.K.; Srivastava, P.; Sangode, S.J.; Nainwal, H.C. A 13,000year record of environmental magnetic variations in the lake and peat deposits from the Chandra valley, Lahaul: Implications to Holocene monsoonal variability in the NW Himalaya. Palaeogeogr. Palaeoclimatol. Palaeoecol. 2015, 440, 116-127. [CrossRef]

80. Gupta, A.K.; Das, M.; Anderson, D.M. Solar influence on the Indian summer monsoon during the Holocene. Geophys. Res. Lett. 2005, 32. [CrossRef] 
81. Yadav, R.R.; Braeuning, A.; Singh, J. Tree ring inferred summer temperature variations over the last millennium in western Himalaya, India. Clim. Dyn. 2011, 36, 1545-1554. [CrossRef]

82. Sinha, A.; Berkelhammer, M.; Stott, L.; Mudelsee, M.; Cheng, H.; Biswas, J. The leading mode of Indian Summer Monsoon precipitation variability during the last millennium. Geophys. Res. Lett. 2011, 38. [CrossRef]

83. Liang, F.; Brook, G.A.; Kotlia, B.S.; Railsback, L.B.; Hardt, B.; Cheng, H.; Edwards, R.L.; Kandasamy, S. Panigarh cave stalagmite evidence of climate change in the Indian Central Himalaya since AD 1256: Monsoon breaks and winter southern jet depressions. Quat. Sci. Rev. 2015, 124, 145-161. [CrossRef]

84. Richards, B.W.; Owen, L.A.; Rhodes, E.J. Timing of Late Quaternary glaciations in the Himalayas of northern Pakistan. J. Quat. Sci. 2000, 15, 283-297. [CrossRef]

85. Owen, L.A.; Finkel, R.C.; Caffee, M.W. A note on the extent of glaciation throughout the Himalaya during the global Last Glacial Maximum. Quat. Sci. Rev. 2002, 21, 147-157. [CrossRef]

86. Gayer, E.; Lavé, J.; Pik, R.; France-Lanord, C. Monsoonal forcing of Holocene glacier fluctuations in Ganesh Himal (Central Nepal) constrained by cosmogenic 3He exposure ages of garnets. Earth Planet. Sci. Lett. 2006, 252, 275-288. [CrossRef]

87. Smith, J.A. Early Local Last Glacial Maximum in the Tropical Andes. Science 2005, 308, 678-681. [CrossRef] [PubMed]

88. Thompson, L.G.; Mosley-Thompson, E.; Davis, M.E.; Mashiotta, T.A.; Henderson, K.A.; Lin, P.-N.; Tandong, Y. Ice core evidence for asynchronous glaciation on the Tibetan Plateau. Quat. Int. 2006, 154-155, 3-10. [CrossRef]

89. Bisht, P.; Ali, S.N.; Shukla, A.D.; Negi, S.; Sundriyal, Y.P.; Yadava, M.G.; Juyal, N. Chronology of late Quaternary glaciation and landform evolution in the upper Dhauliganga valley, (Trans Himalaya), Uttarakhand, India. Quat. Sci. Rev. 2015, 129, 147-162. [CrossRef]

90. Eugster, P.; Scherler, D.; Thiede, R.C.; Codilean, A.T.; Strecker, M.R. Rapid Last Glacial Maximum deglaciation in the Indian Himalaya coeval with midlatitude glaciers: New insights from 10 Be-dating of ice-polished bedrock surfaces in the Chandra Valley, NW Himalaya. Geophys. Res. Lett. 2016, 43, 1589-1597. [CrossRef]

91. Owen, L.A.; Caffee, M.W.; Bovard, K.R.; Finkel, R.C.; Sharma, M.C. Terrestrial cosmogenic nuclide surface exposure dating of the oldest glacial successions in the Himalayan orogen: Ladakh Range, northern India. Geol. Soc. Am. Bull. 2006, 118, 383-392. [CrossRef]

92. Bhattacharya, A. Vegetation and climate during the last 30,000 years in Ladakh. Palaeogeogr. Palaeoclimatol. Palaeoecol. 1989, 73, 25-38. [CrossRef] 